University of Nebraska - Lincoln

DigitalCommons@University of Nebraska - Lincoln

$7-2020$

\title{
Metacritiques of Upper Echelons Theory: Verdicts and Recommendations for Future Research
}

Brett H. Neely Jr.

Jeffrey B. Lovelace

Amanda P. Cowen

Nathan J. Hiller

Follow this and additional works at: https://digitalcommons.unl.edu/managementfacpub

Part of the Business Administration, Management, and Operations Commons, Management Sciences and Quantitative Methods Commons, and the Strategic Management Policy Commons

This Article is brought to you for free and open access by the Management Department at DigitalCommons@University of Nebraska - Lincoln. It has been accepted for inclusion in Management Department Faculty Publications by an authorized administrator of DigitalCommons@University of Nebraska - Lincoln. 


\title{
Metacritiques of Upper Echelons Theory: Verdicts and Recommendations for Future Research
}

\author{
Brett H. Neely Jr., ${ }^{1}$ Jeffrey B. Lovelace, ${ }^{2}$ \\ Amanda P. Cowen, ${ }^{2}$ and Nathan J. Hiller ${ }^{3}$ \\ 1 University of Nebraska-Lincoln \\ 2 University of Virginia \\ 3 Florida International University \\ Corresponding author - Brett H. Neely Jr., College of Business, University of Nebraska-Lincoln, \\ 730 N. 14th Street, P.O. Box 880405 Lincoln, NE 68588, USA. Email: bhneely3@gmail.com \\ ORCID \\ Brett H. Neely https://orcid.org/0000-0003-3065-1333
}

\begin{abstract}
After more than 35 years, Hambrick and Mason's upper echelons theory (UET) stands as one of the most influential perspectives in management research. However, as the literature and its attendant reviews have become more numerous and specialized, discussion of the fundamental conceptual and methodological critiques leveled against research utilizing the UET perspective has grown fragmented. As such, the first aim of the present review is to identify and synthesize a set of common critiques levied against UET research. In doing so, we unpack important nuance within each critique while establishing a common vocabulary to facilitate greater consistency in how these critiques are discussed by scholars, editors, and reviewers. Next, we analyze the past decade of UET research (i.e., empirical and conceptual articles) to provide a progress report on the state of the literature as it pertains to each critique. Based on this analysis, we issue a "verdict," providing clear guidance on what issues still need to be resolved and
\end{abstract}

Published in Journal of Management 46:6 (July 2020), pp 1029-1062.

DOI: $10.1177 / 0149206320908640$

Copyright (C) 2020 Brett H. Neely Jr., Jeffrey B. Lovelace, Amanda P. Cowen, and Nathan J. Hiller. Published by SAGE Publications. Used by permission. 
offering clear recommendations for UET scholars moving forward. Finally, we close by taking stock of how our recommendations position UET scholars to embrace the task of providing impactful insights on emerging challenges facing top executives.

Keywords: leadership, strategic leadership, top management teams/upper echelon, CEO, decision making

Hambrick and Mason's (1984) upper echelons theory (UET) has been established as one of the most influential perspectives in the strategic management literature. The theory has served as a catalyst for examining how executives' characteristics and experiences shape their perceptions, choices, and actions in ways that ultimately impact a variety of firm outcomes (e.g., Bromiley \& Rau, 2016; Hodgkinson \& Sparrow, 2002; Wang, Holmes, Oh, \& Zhu, 2016). From 2000 to 2009, a number of influential reviews took stock of how UET research progressed over its first two decades (e.g., Carpenter, Geletkanycz, \& Sanders, 2004; Hambrick, 2005, 2007), culminating with the updated publication of Finkelstein, Hambrick, and Canella's comprehensive book, Strategic Leadership, in 2009. While these reviews summarized the growing evidence in support of UET's core premise, they also set forth several broad critiques about the conceptual and methodological limitations of the existing literature and charted new directions for research going forward.

Today, interest in the influence of top executives remains strong, and even a cursory inspection of the literature provides clear evidence that scholars have made headway on topics ranging from executive cognition and personality (e.g., Harrison, Thurgood, Boivie, \& Pfarrer, 2019; Lovelace, Bundy, Hambrick, \& Pollock, 2018) to alternative strategic actions (e.g., Gupta, Briscoe, \& Hambrick, 2017; Wright \& Nyberg, 2017) to the influence of compensation schemes (e.g., Benischke, Martin, \& Glaser, 2019; Hafenbradl \& Waeger, 2016). As research has accumulated, several dozen literature reviews related to UET have been published. These reviews typically examine specific aspects of UET research (e.g., CEOs' impact on firm performance; executive cognition, or personality; Smith, Hill, Wallace, Recendes, \& Judge, 2018; Wang et al., 2016) or discuss its contributions to other research streamsfor example, the literature on organizational change, strategic interfaces, or managerial risk taking (Hoskisson, Chirico, Zyung, \& Gambeta, 2017; Hutzschenreuter, Kleindienst, \& Greger, 2012; Oreg \& Berson, 
2018; Simsek, Heavey, \& Fox, 2018). Such work has facilitated consolidation of the research pertinent to specific research areas and provided broad support for UET's validity and relevance to strategic management scholarship.

However, as the literature and its attendant reviews have grown more numerous and specialized, a comprehensive examination of the fundamental critiques that have been leveled against UET has gone overlooked. Indeed, the proliferation of reviews pertaining to UET research has, in many ways, compounded the challenge of developing a shared understanding of these critiques. It is common for reviews to employ language used by earlier critics but with a different intended meaning. For example, charges of a "black box" are ubiquitous, yet what that "box" is-executives' cognitive processes, their behaviors, their interactions with top managers-varies from review to review (e.g., Carpenter et al., 2004; Hambrick, 2007; Klotz, Hmieleski, Bradley, \& Busenitz, 2014). In other cases, reviewers use different terminology (e.g., "selection bias," "unobserved heterogeneity", "causality") to describe what is essentially the same critique (e.g., endogeneity; Hambrick, 2005; Hiller, DeChurch, Murase, \& Doty, 2011; Hoskisson et al., 2017). Furthermore, as reviews have become narrower in their focus, there has been limited effort to systematically evaluate whether progress has been made in addressing these critiques across the broader UET research stream. Thus, scholars, editors, and reviewers lack a shared understanding of whether there is closure on these issues and what constitutes "best practice." Such understanding is critical to facilitating UET research that can successfully engage with emerging phenomena and offer insights of value to leaders and their organizations.

In this review, we seek to address this problem by identifying and evaluating what we term "metacritiques" of UET research. We do this by first examining reviews and meta-analyses relevant to UET that were published since its introduction in 1984 . We systematically code these articles in an effort to aggregate criticisms of UET made across a variety of related literatures and to identify and synthesize those critiques that span research domains. The resulting metacritiques are not simply standard "calls for more research" or criticism of mixed empirical findings that typically often appears in reviews. Rather, they raise more fundamental questions about what constitutes robust approaches to theorizing and empirical testing in UET scholarship. In synthesizing each 
critique, we look to acknowledge the important nuances within it while also developing a vocabulary that can facilitate greater consistency in how the critique is discussed. We then turn our attention to reviewing recent research developments pertinent to each critique. Specifically, we investigate the past decade of UET research in order to assess and report what progress, if any, has been made. Finally, we issue a "verdict" on each critique, offering clear guidance on what issues are resolved or remain open, and provide recommendations for the research community moving forward.

There are several reasons that the time is ripe for this undertaking. In addition to the expanding research base on UET topics, there are also signs that the core phenomenon itself is changing. Considerable evidence suggests that executives today have even greater impact on firm actions and performance than they did in the past (e.g., Mackey, 2008; Quigley \& Hambrick, 2015). Thus, from the standpoint of both research trajectory and phenomenological importance, the UET literature is likely to continue to grow, further complicating efforts to examine issues that span different research streams. At the same time, the world around organizations is also transforming - technologically, politically, economically, socially - in ways that may have profound implications for the role of executives and their influence on firms as well as on society (e.g., Hambrick \& Quigley, 2014; Wright \& Nyberg, 2017). Don Hambrick, one of the pioneers of UET, recently argued that these conditions present unique opportunities for researchers: to advise leaders on how to confront a shifting environment and to leverage our existing UET research platform to take on broader questions (Hambrick, 2019). Yet fundamental issues are also now being raised regarding the transparency, replicability, and applicability of social science research, including management research (e.g., Kohler \& Cortina, in press; Rynes, Colbert, \& O’Boyle, 2018). So while the relevance of the UET perspective may be increasing, so are the challenges of executing sound studies-underscoring the importance of addressing the metacritiques we examine in this review. In doing so, we believe future UET research efforts will ultimately be more successful and impactful.

The remainder of this review proceeds as follows. In the next section, we describe the procedure used to identify the five metacritiquesthree conceptual and two methodological. We then explain how we identified and reviewed the past decade of UET research in order to assess 
the progress made on each critique. In addition, we offer concrete, forward-looking recommendations for all five critiques. Finally, we close by discussing how these issues are taking on new meaning and importance in today's environment and suggest ways that UET researchers can approach these changes as opportunities for increased impact.

\section{Identifying Metacritiques of UET Research}

Since the introduction of UET, there have been a host of reviews and meta-analyses that have addressed the evidence in support of the theory and-more importantly for our objectives - that have also articulated fundamental critiques of UET research. To locate relevant review efforts, we searched for the terms "UET" or "upper echelon" or "upper echelons" anywhere in journal articles published between 1984 and 2019. We focused our initial search on journals that routinely publish literature reviews: Academy of Management Annals, Journal of Management, and Leadership Quarterly. To further refine this list, a member of the author team reviewed each article to ensure it had relevance to UET. We also added relevant books, chapters, and summative journal efforts (e.g., other reviews or meta-analyses) that came to our attention while processing our initial sample of review articles. Ultimately, we identified 35 articles that met our criteria.

Next, we examined each article, with a particular focus on discussion of UET-related critiques. Based on this examination, we distilled five broad categories of UET critiques: two conceptual (cognitive processing and conceptual complexity) and three methodological (measurement validity, proxy variable use, and endogeneity). After identifying these categories, each review article was then reexamined to assess (a) whether it contained material relevant to one of these categories and (b) whether it leveled any other criticisms against UET that were not accounted for in our initial coding scheme. Our intent was not to catalog individual research questions raised but rather to focus on broad issues regarding conceptual development and methodological approaches in UET research.

After completing this procedure, the author team reviewed the results and, through discussion, refined the initial categories. Two of these categories (cognitive processing and endogeneity) were retained without 


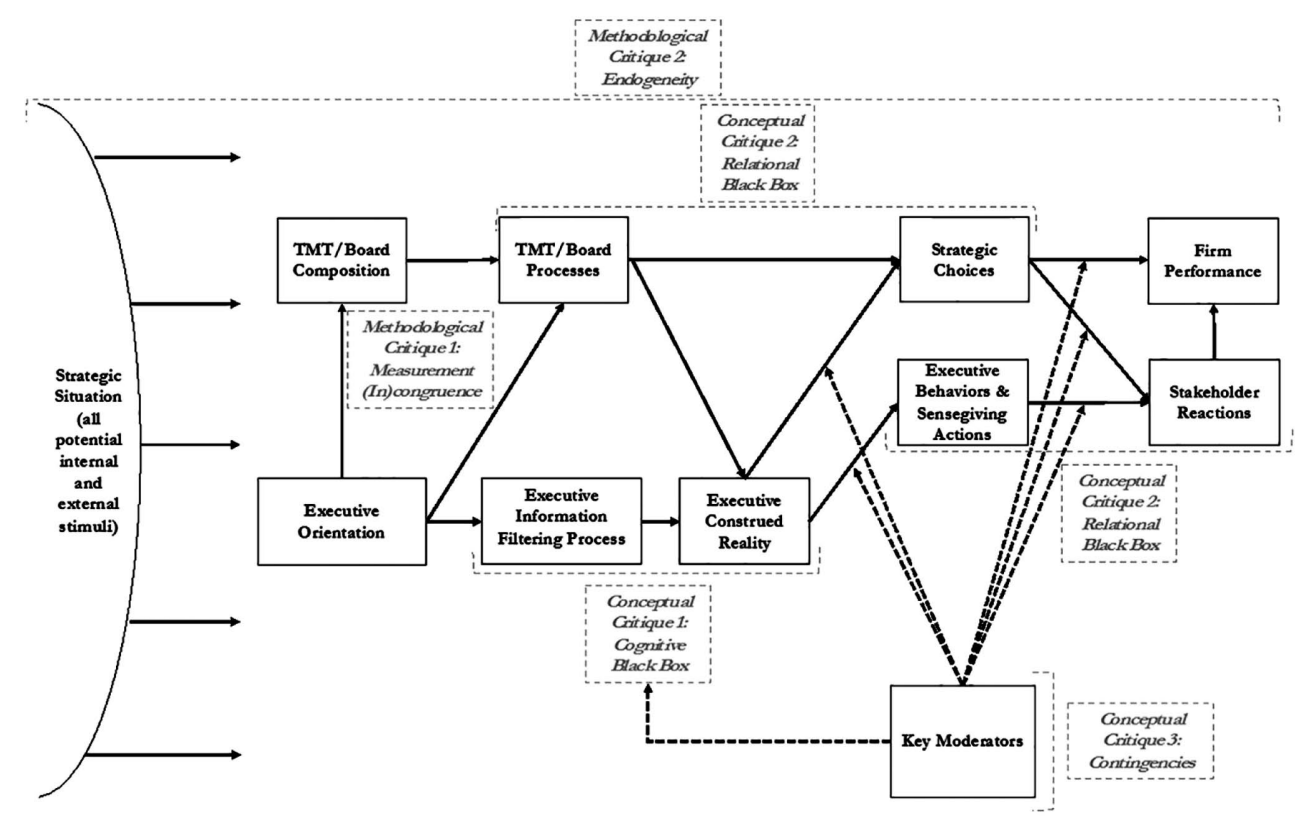

Figure 1 Position of Metacritiques Within the Upper Echelons Theory Process Model Source: Adapted from Abatecola et al. (2018); Finkelstein, Hambrick, and Cannella (2009); Hambrick (2005); Liu et al. (2018); Oreg and Berson, 2018; Wang, Holmes, Oh, and Zhu (2016).

Note: Of the 35 review articles evaluated, 17 referred to Conceptual Critique 1, 27 to Conceptual Critique 2, 22 to Conceptual Critique 3, 18 to Methodological Critique 1 , and 13 to Methodological Critique 2. See Supplemental Table 1 for full coding results.

modification (now labeled Conceptual Critique 1 and Methodological Critique 2, respectively). A third category, conceptual complexity, was subsequently divided into two separate critiques (Conceptual Critiques 2 and 3). Finally, the other two preliminary categories (proxy variable use and measurement validity) were integrated into a single critique (Methodological Critique 1). See Table 1 for a summary of our discussion of each UET metacritique. During our coding process, we also collected conceptual depictions of UET (i.e., figures) that appeared in these articles. These figures illustrated a variety of conceptual extensions to the original UET framework. In Figure 1, we integrate these additions into an updated conceptualization of UET and highlight aspects of the theory pertinent to each metacritique. Additionally, a supplemental table shows the coding results for the 35 review articles. 


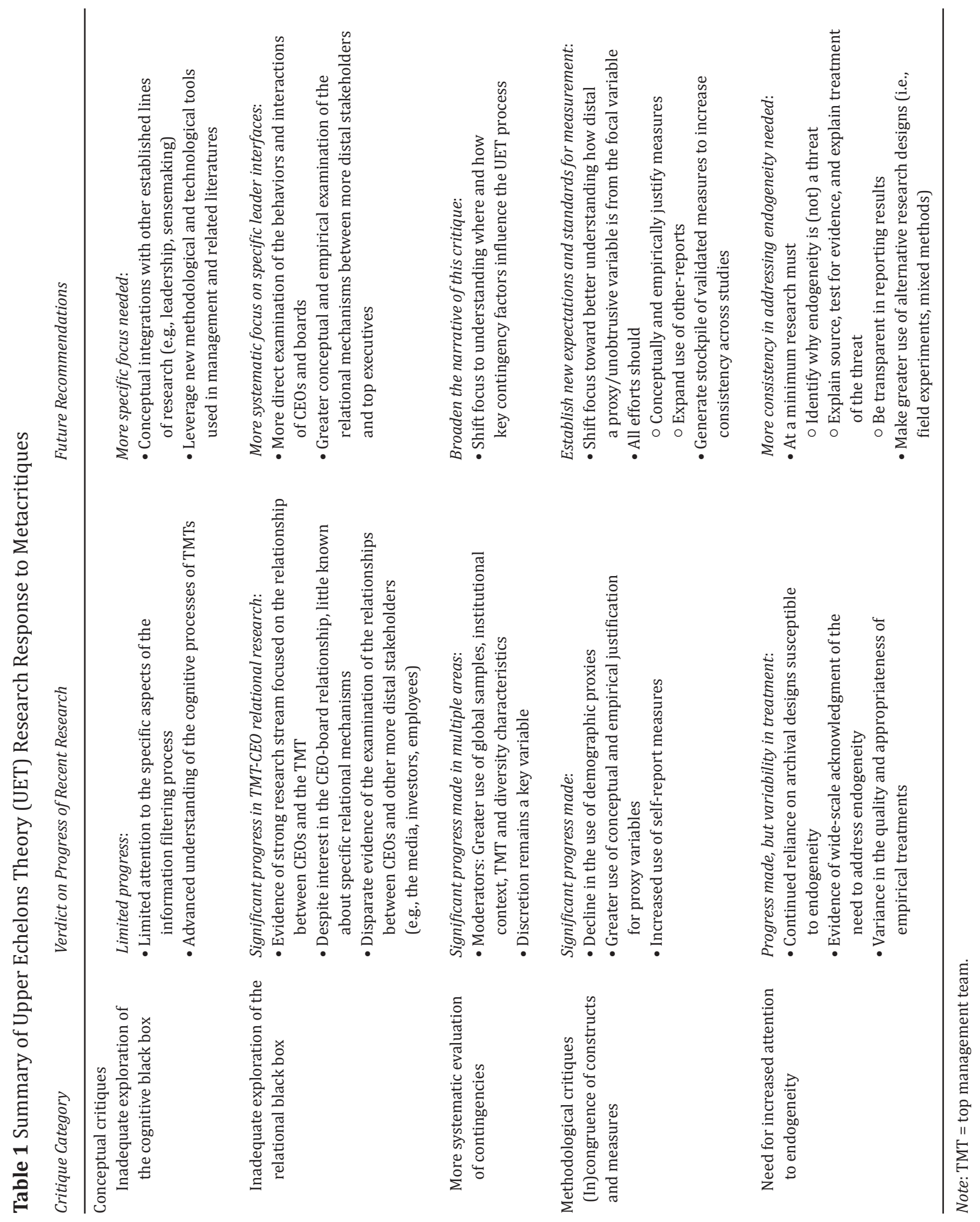




\section{Evaluating Progress Made on UET Metacritiques}

In discussing each of the five resulting metacritiques, we first synthesize the central conceptual or methodological charges made in prior reviews, then assess recent progress, and finally, close each section by issuing a verdict on the state of the science and offering best practices for UET research moving forward. To facilitate these latter goals, we collected and reviewed primary UET research (i.e., not literature reviews or meta-analyses) published since 2009 . We used 2009 as the starting point for our search to coincide with the publication of Finkelstein and colleagues' (2009) book, which offered a comprehensive review of UET research to that point.

We identified our sample of UET research articles by following the guidelines set forth by Short (2009) and by supplementing these with best practices drawn from high-impact reviews and editorials (e.g., Carpenter et al., 2004; Parmigiani \& King, 2019). Our search process included using online databases to search for UET-related terms in the text of articles that appeared in 14 leading U.S. and non-U.S. journals that publish macro and/or micro research. We then reviewed the results produced by this search and excluded any articles that did not substantively leverage the UET perspective (e.g., only had the term "upper echelon[s]" in a reference list but did not significantly address relevant concepts). A complete description of our search procedure and the final set of 217 articles we identified appear in the online supplement.

Conceptual Critique 1: Inadequate Exploration of the Cognitive Black Box

The influence of the UET perspective has, in part, stemmed from its ability to connect executive characteristics to seemingly distal outcomes, such as firm actions and performance. However, as a result, UET studies have also often been criticized for lack of attention to the process mechanisms that mediate the relationship between executive orientation and firm outcomes (e.g., Bluedorn, Johnson, Cartwright, \& Barringer, 1994; Cragun, Olsen, \& Wright, in press; Menz, 2012). Critics have suggested that this black box limits the conceptual, and especially the practical, contributions of the theory. In our evaluation of past UET-related reviews, we found that these black-box critiques actually pertain to two distinct conceptual issues. The first concerns the lack of explicit 
exploration of executives' cognition processes; the second pertains to relational processes.

Individual and group cognition play a central role in the conceptual foundation of UET (Carpenter et al., 2004; Hambrick, 2007). Broadly, there is an understanding that cognitive models affect how individuals attend to, filter, and process information in a given situation. UET explains that these cognitive processes influence executives' decisions and actions (e.g., Finkelstein et al., 2009; Hambrick \& Mason, 1984; Hodgkinson \& Sparrow, 2002). Prior reviews argue that more direct and indepth examinations of cognitive process are needed to open up the proverbial black box linking executive cognition to a firm's strategic actions (e.g., Bromiley \& Rau, 2016; Felin, Foss, \& Ployhart, 2015; Hodgkinson \& Sparrow, 2002). More specifically, previous reviews advocated for investigation of the influence of executive characteristics and experiences on specific aspects of executives' cognitive processes, including what information executives look for (i.e., limited field of vision), attend to (i.e., selective perception), and deem important (i.e., interpretation).

Review of recent progress. Our review of recent UET literature revealed significant activity in the area of executive cognition (e.g., Bilgili, Calderon, Allen, \& Kedia, 2017; Chen \& Nadkarni, 2017; Hafenbradl \& Waeger, 2016; Steinbach, Gamache, \& Johnson, 2019). On the conceptual side, while most efforts do not examine the specific steps of the information-filtering process, research has grown more explicit in theorizing about the link between executive characteristics and cognitive processes as well as in specifying the impact of contextual conditions (e.g., retirement, crisis, change; Bilgili et al., 2017; Hahn, Preuss, Pinkse, \& Figge, 2014; Konig, Graf-Vlachy, Bundy, \& Little, 2020). For example, Lovelace and colleagues (2018) theorize that when CEOs become celebrities, their cognitive processes change; they are less deliberative yet more confident in their decision making. The authors explain how these consequences are enhanced by individual characteristics (e.g., narcissism) as well as how contextual conditions (e.g., environmental continuity vs. change) may constrain the impact of cognitive changes on behavioral outcomes. Helfat and Peteraf (2015) go a bit farther in pulling apart specific aspects of cognition. They introduce the concept of "managerial cognitive capability," which refers to an executive's capacity to engage in the generation, retrieval, and modification of knowledge structures (i.e., "mental 
activities"). The authors explain how this cognitive capability shapes managers' ability to perceive and attend to opportunities in the environment, subsequently impacting strategic change and firm performance.

On the empirical side, a limited number of studies have examined how executives utilize specific information (i.e., what information they look for, perceive, and interpret) when making decisions and how this process interacts with other executive characteristics. There has been a particular focus on the manifestation of such processes within the top management team (TMT; e.g., Heavey, Simsek, Roche, \& Kelly, 2009; Li, Maggitti, Smith, Tesluk, \& Katila, 2013; Mannor, Wowak, Bartkus, \& Gomez-Mejia, 2016; Samba, Williams, \& Fuller, in press). As an example, Heavey and Simsek $(2015,2017)$ have advanced understanding of the cognitive structure and functioning of teams through the investigation of transactive memory within TMTs. Their findings help explain the mechanisms (e.g., ambidextrous orientation) and environmental factors (e.g., TMT diversity, strength of network ties) that influence the effect of TMT cognition on firm performance.

Other studies have approached executive cognition at the individual level. For example, Mannor and colleagues (2016) worked to unpack executives' cognitive models in their examination of how job anxiety affects decision making in gain-versus-loss contexts. The authors not only directly measured executives' psychological characteristics but also used multiple research methods to gain insight into how these shaped the information-filtering process. They found that more anxious executives make less risky strategic decisions but that these effects are dependent on context. Similarly, Pryor, Holmes, Webb, and Liguori (2019) examined the impact of executive goal orientation and environmental scanning on firm performance, demonstrating how field of vision and selective perception affect strategic outcomes. Even with these recent advancements, however, many opportunities remain to more fully understand the nuances of executives' cognitive processes.

The verdict: Where do we go from here? While several studies from the past decade have advanced the understanding of executives' cognitive structure and processes, overall progress in this area is rather limited. This is a function of the complexity and multifaceted nature of cognition, the challenges in accessing appropriate data, and the need for more detailed models of executive cognition. To more fully unpack the 
cognitive processes that account for observed relationships, we propose that UET researchers (a) integrate conceptual approaches from related research streams, (b) capitalize on promising methodological techniques used in recent studies, and (c) take advantage of the insights afforded by new technologies.

First, future UET research can benefit from the integration of conceptual models developed in related literatures (e.g., sensemaking and leadership), which have had success in advancing research on individual cognition (e.g., Connelly et al., 2000; Maitlis \& Christianson, 2014; Weick, Sutcliffe, \& Obstfeld, 2005). As an example, research on how cognition and emotion influence leaders' behaviors - and ultimately affect their followers and organizations - has been a major area of focus in micro leadership research (e.g., Bono \& Ilies, 2006; Dinh et al., 2014). Studies in this literature have examined aspects of cognition, such as a leader's sensemaking process in critical situations (e.g., Combe \& Carrington, 2015; Weick, 1995), the role of expertise and experience in leader decision making (e.g., Hedlund et al., 2003), and the development and utilization of leaders' mental models (e.g., Goldvarg \& Johnson-Laird, 2001; Mumford, 2006). For example, Mumford, Todd, Higgs, and McIntosh (2017) reviewed the literature on leader cognition and performance outcomes, identifying nine key cognitive skills that leaders use to solve complex problems (e.g., cause/goal analysis, forecasting, wisdom), with a particular emphasis on implications for leader development and evaluations of effectiveness. Integrating conceptual insights from such studies can help UET researchers to better specify the cognitive mechanisms that guide the decisions and actions of organizational leaders.

Second, there are a variety of recent studies that have used promising new methodological techniques to provide insight into executive cognition. For example, the teams' literature has advanced the validity of using text transcripts and video recordings for the measurement of mental models and transactive memory (e.g. Ellis, 2006; Rowe \& Cooke, 1995). Recent UET research used similar techniques to examine executive personality, and we propose that the application of these approaches could reasonably be extended to studies of executive cognition. Other efforts have leveraged historiometric analysis (i.e., analysis of biographies and other historically relevant content; Crayne \& Hunter, 2018; Sonpar \& Golden-Biddle, 2008) or content analyzed other widely available documents to better understand executives' cognitive processes (see Mannor 
et al., 2016; Resick, Whitman, Weingarden, \& Hiller, 2009; Wowak, Mannor, Arrfelt, \& McNamara, 2016). There are also indications that under some conditions, executives are willing to participate in studies that more directly measure their cognitive characteristics. For example, Westphal and Shani (2016) investigated the impact of self-regulated cognition (i.e., reflection) on board member interactions using longitudinal surveys of director dyads. Future efforts can take advantage of such recent developments to collect higher-quality data about executives' cognitive structures and processes.

Finally, technology is expanding the data sources available to researchers interested in understanding the very foundations of executive cognition. For example, Parkinson, Kleinbaum, and Wheatley (2017) recently used functional magnetic resonance imaging (fMRI) to explore how business school students cognitively encode relational data and how such differences correspond to real-world interactions. Such neuropsychological (e.g., fMRI, electroencephalogram [EEG]; Healey \& Hodgkinson, 2014; Tivadar \& Murray, 2019; Waldman, Wang, \& Fenters, 2019) and physiological (e.g., skin conductance, heart rate, genetic factors; Ganster, Crain, \& Brossoit, 2018) data have become increasingly accessible as technologies improve and become less obtrusive over time (e.g., mobile health trackers, portable EEG). Pragmatically, less mobile technologies (fMRIs) are probably best reserved for use with more accessible groups, such as MBA students or executive education participants. However, mobile technologies, such as EEGs or wearable trackers, appear viable for use with field samples of executives, especially if researchers can articulate clear benefits to participation. Such devices create tremendous opportunity for exploring the connection between the biological and neurological foundations of cognition and the decision-making processes of executives (Butler, O’Broin, Lee, \& Senior, 2016). That said, researchers must not lose sight of the socially embedded nature of organizational life; these data should complement traditional measures not supplant them (Healey \& Hodgkinson, 2014; Tivadar \& Murray, 2019). Additionally, there are important ethical concerns (e.g., privacy and health risks) that researchers must be prepared to address to ensure that subjects' biodata are protected (Jack, Rochford, Friedman, Passarelli, \& Boyatzis, 2019; Loued-Khenissi, Doll, \& Preuschoff, 2019). Collaborating with researchers knowledgeable about managing such issues is advisable for scholars new to these technologies. Indeed, such 
collaborations may open up access to new populations and allow scholars to leverage interdisciplinary insights in exploring cognitive processes that underlie key relationships.

Leveraging these conceptual and methodological strategies can position researchers to investigate new questions pertaining to executive cognition, such as the following: How do certain developmental experiences (e.g., "turning points") change executives' cognitive structures and influence their decision making over time? How and why do executives focus on different types of information in the sensemaking and sense giving processes? Are there neuropsychological or biological indicators of executive cognition? In sum, by integrating conceptual knowledge from other research areas, capitalizing on recent methodological techniques, and judiciously using biotechnologies, UET researchers can make progress in unpacking the cognitive black box.

\section{Conceptual Critique 2: Inadequate Exploration of the Relational Black Box}

We now turn our attention to the second way in which black-box critiques have been applied: the limited attention paid to leader, TMT, and stakeholder interactions as important process mediators-the relational black box. There have been repeated calls for research that examines the behavioral manifestations of executive orientation and how such behavior influences the relationships, motivations, and actions of the various stakeholders that ultimately shape firm outcomes (Chen \& Miller, 2012; Felin et al., 2015; Klotz et al., 2014; Wowak, Gomez-Mejia, \& Steinbach, 2017). More specifically, previous reviews called for greater focus on how executive characteristics influence the dynamics between executives and between managers and the board and even how they may impact more distal stakeholders (e.g., employees, the media, investors). By unpacking this relational black box, critics suggest that scholars can develop a richer understanding of how leaders can and should operate in their organizations to facilitate successful outcomes (Bluedorn et al., 1994; Helfat \& Martin, 2015).

Review of recent progress. Earlier reviews focused primarily on the need to understand the mediating role of TMT dynamics (e.g., Carpenter et al., 2004; Finkelstein et al., 2009; Hambrick, 2007), and here we have seen increased focus over the past decade. Indeed, research on 
"strategic interfaces" has grown to the point that it now merits literature reviews of its own (e.g., Bromiley \& Rau, 2016; Georgakakis, Heyden, Oehmichen, \& Ekanayake, in press; Simsek et al., 2018). Strategic interfaces concern the "social situations in which the attributes, aspirations, and/or activities of strategic leaders and/or salient stakeholders come into contact with and influence each other" (Simsek et al., 2018: 283). In practice, however, this work varies considerably in how directly it examines behaviors and relational processes instead of simply looking at interactions between leader or team characteristics. Our review identified numerous articles in this, and related, research streams that have begun to unpack these (behavioral, relational, and TMT dynamics) aspects of the black box (e.g., Heyden, van Doorn, Reimer, Van Den Bosch, \& Volberda, 2013; Qian, Cao, \& Takeuchi, 2013; Raes, Heijltjes, Glunk, \& Roe, 2011). For example, Clark and Maggitti (2012), in a field study of public high-technology firms, provided insight into how TMT potency-confidence in a team's ability to be effective-partially mediates the process through which TMT knowledge, experience, and interactional processes (e.g., participation, affective conflict, and cognitive conflict) influence strategic decision speed. As another example, in an experimental study, Jung, Vissa, and Pich (2017) found that within entrepreneurial founding teams, members' diffuse status cues (e.g., gender, ethnicity, or achievement) and specialized expertise affected outcomes because these characteristics shaped the way the team selected members for leadership roles (e.g., CEO).

Other TMT studies have leveraged the broader leadership literature to unpack how relational processes help to explain firm performance (e.g., Carmeli, Schaubroeck, \& Tishler, 2011; Peterson, Galvin, \& Lange, 2012; Resick et al., 2009; Stoker et al., 2012). In a time-series surveybased study of firms in the Chinese telecom industry, Zhang, Li, Ullrich, and van Dick (2015) found that inconsistencies in a CEO's transformational leadership behaviors toward team members disrupted overall team dynamics. They also had negative implications for team effectiveness and firm performance. These results were stronger when the CEO was female and when CEOs also displayed moral inconsistencies in their behavior. Additionally, Ou and colleagues (2014) found that CEO humility was associated with empowering leadership behaviors, which in turn positively related to TMT integration (i.e., member willingness to collaborate, share information, make joint decisions, and develop a shared 
vision). In turn, TMT integration positively related to middle managers' perceptions of the organization as empowering, which was associated with higher levels of work engagement, affective commitment, and job performance. As such, the study was able to demonstrate the process by which a leader's orientation and behavior have implications for stakeholders across multiple levels of the organization.

While somewhat less common, work with implications for relational dynamics at the board level was also identified (e.g., Bao, Fainshmidt, Nair, \& Vracheva, 2014; Boivie, Graffin, \& Pollock, 2012; Quigley \& Hambrick, 2012; Stern \& Westphal, 2010). For example, Tuggle, Schnatterly, and Johnson (2010) found that boards with greater heterogeneity on certain dimensions (i.e., output functions) allocate more attention to entrepreneurial issues. Further, their findings indicted that CEOs could affect the time directors spent discussing firm entrepreneurial issues, depending on how the board and its meetings were structured. As another example, Sauerwald, Lin, and Peng (2016) found that CEO influence may undermine monitoring norms among directors, resulting in less board resistance to "excess" CEO rewards.

Finally, we also identified a handful of studies that explored the relational mechanisms that govern the interface between executives and more distal stakeholders (e.g., employees, the media, competitors, consumers; e.g., Jacquart \& Antonakis, 2014; Resick et al., 2009; Wang, Tsui, \& Xin, 2011; Yi, Zhang, \& Windsor, in press). As an illustration, Hill, Recendes, and Ridge (2019) utilized video metric techniques to identify how a CEO's submissiveness and provocativeness led to more competitive actions directed toward their organization, helping to demonstrate the implications of rivals' perceptions of a CEO. Cowen and Montgomery (2020) found that consumer reactions to product failure were influenced by the interaction of a CEO's gender with how accommodative they were in their post failure communications. Consumers' reactions to male-led organizations did not depend on accommodativeness, but female-led firms received a more favorable response when their CEOs utilized more accommodative language. The authors found that such differences are attributable to how CEO gender shapes audiences' perceptions of the fairness of post failure communications. Finally, Westphal, Park, McDonald, and Hayward (2012) found that executives engage in impression management to influence journalists' reactions to performance decline at a fellow executive's firm. These impression management "support" 
activities take several forms (e.g., commenting on another CEO's leadership abilities, explaining why a firm's low performance is due to uncontrollable environmental factors) and influence how journalists react to negative earnings surprises even more than impression management efforts by the firm's own CEO. The authors suggest that a norm of reciprocity between CEOs explains this advocacy on each other's behalf. Such studies provide insights into the implications that executive behaviors have for stakeholders beyond the TMT.

The verdict: Where do we go from here? Our review of the past decade of research revealed significant progress in teasing out relational mechanisms within the TMT and between TMTs and CEOs (for in-depth reviews, see Bromiley \& Rau, 2016; Simsek et al., 2018). Because the nature of relationships, behaviors, and influence in any system is complex and multifaceted (including at the upper echelons of organizations), there remains value in further considering relational issues at the CEOTMT interface (Menz, 2012). That said, we also see tremendous opportunity in the study of both CEO-board relationships and CEOs' relationships with more distal stakeholders.

First, while the CEO-board interface is a key area of interest for researchers, it continues to be studied at a distance. This work is valuable but for it to have more impact, it is critical to find novel ways to unlock the boardroom and step inside. As Wowak and colleagues (2016) note, difficulty in gaining access to a certain population does not justify failure to pursue important research questions. As such, it is essential that future efforts aim to more directly investigate the interplay of executive/board relationships on firm outcomes. Access to boards is highly restricted; however, large samples are not necessarily required. Qualitative researchers are adept at utilizing focused samples to examine and articulate processes in management research (Pratt, 2009), which could prove useful for furthering the understanding of the relational black box. For example, Smith (2014) examined how leaders simultaneously handle competing strategic demands by using rich data from TMTs in six strategic business units for one Fortune 500 company. Combining interviews, observations, and archival data, she developed a model of dynamic decision making through which strategic paradoxes can be effectively managed. This kind of qualitative approach may be particularly well suited for research into relational mechanisms at the board level. 
Echoing this sentiment, Lorsch (2017) argued that the best path forward for this governance research is to study boards as dynamic social systems, something that cannot be accomplished without direct observation of environments and processes.

Next, while some work has examined the relational mechanisms through which executives influence more distal stakeholders, there remain many opportunities on this research front. More specifically, the "followership" perspectives emerging in the broader leadership domain (e.g., Epitropaki, Kark, Mainemelis, \& Lord, 2017; Uhl-Bien, Riggio, Lowe, \& Carsten, 2014) highlight the opportunity to conceptually and empirically investigate the influence of other stakeholders on the UET process. As an example, in their discussion of executive symbolic actions, Hambrick and Lovelace (2018) theorized about how the nature of an executive's symbolic actions influences employee engagement with new strategic themes. However, they also highlighted that influence operates in both directions. Employees' predisposition toward a strategic theme (ranging from strongly negatively to strongly positively predisposed) also influences an executive's ability to elicit positive responses. Likewise, Gamache and McNamara (2019) examined how negative media reactions to an acquisition influence future acquisition activity by a firm given a CEO's temporal focus, again highlighting how more distal stakeholders influence executive decision-making processes (Pfarrer et al., 2019). Finally, social media platforms offer new data sources for examining executives' interactions with stakeholders (e.g., Hill, White, \& Wallace, 2014). Kim and Youm (2017) leveraged such data in their study of how firm-initiated Twitter messages affected analyst recommendations, mediated by customer reactions.

While recent UET research has significantly advanced our understanding of the relational black box, there remain important opportunities to further this work. First, by opening the boardroom to more direct investigations, researchers will be able to ask questions about how relational dynamics (e.g., norms, patterns of interaction between directors) shape boards' effectiveness in monitoring CEOs, making strategic decisions, and managing growing external pressure from shareholders and activists. Likewise, by devoting attention to more distal stakeholders, UET scholars can consider questions such as, How are executives engaging with customers or other audiences on social media platforms to influence public sentiment or firm outcomes? In turn, what effect do 
these more distal stakeholders have on executives' decisions regarding environmental or social issues? As such, by continuing to explore relational issues at the CEO-TMT interface and placing greater emphasis on both CEO-board relationships and CEOs' relationships with more distal stakeholders, researchers can further our understanding of UET's underlying mechanisms.

\section{Conceptual Critique 3: More Systematic Evaluation of Contingencies}

Over three decades, both reviews and meta-analyses have raised concerns about inconsistent empirical findings across UET studies. Early reviews tended to attribute mixed findings to the use of unreliable proxy variables (Hodgkinson \& Sparrow, 2002; Markoczy, 1997; Pettigrew, 1992). More recently, scholars have highlighted the role of contextual factors in moderating the influence of executive characteristics on firm outcomes (e.g., Busenbark, Krause, Boivie, \& Graffin, 2016; Wang et al., 2016). To this end, critics have called for greater attention to theoretically and empirically specifying conditions under which key predictions are supported.

The introduction of managerial discretion (Hambrick \& Finkelstein, 1987) and job demands (Hambrick, Finkelstein, \& Mooney, 2005) as key moderators of UET relationships represented important early progress in addressing this critique. As the literature has developed, more recent review pieces have pushed for the examination of a wider variety of contextual factors that impact the influence of executive orientation on firm outcomes, including national setting, corporate governance practices, and differences in TMT member backgrounds (Bromiley \& Rau, 2016; Carpenter et al., 2004; Crossland \& Hambrick, 2011; Finkelstein, 1992; Hambrick, 1995, 2007). Past reviews have also suggested that researchers consider how different executive characteristics may interact to shape the processes through which executives' perceptions and decisions are formed (Finkelstein et al., 2009; Hodgkinson \& Sparrow, 2002). The hope in doing this is that inconsistent findings can be reconciled and the boundary conditions of UET better understood. Both, critics argue, are essential to the future progress of UET research and its ability to offer meaningful insights to practicing managers. 
Review of recent progress. Moderating conditions have been a key focus of UET research over the past decade. First, with respect to contextual characteristics, we noted a growing focus on the role of institutional context. As businesses today operate in increasingly globalized conditions, scholars have become increasingly interested in how the principles of UET apply across cultures (e.g., Quigley \& Hambrick, 2015). This has been achieved, in part, by studies that use mixed or non-U.S.-based samples (e.g., Hafenbradl \& Waeger, 2016; Han, Jennings, Liu, \& Jennings, 2019; Zhang, Ou, Tsui, \& Wang, 2017), which were far less common in earlier periods. There have also been several studies that considered the importance of executives' global exposure (e.g., Crossland \& Hambrick, 2011; Mohr \& Batsakis, 2018; Nielsen \& Nielsen, 2013; Quigley \& Hambrick, 2012). For example, Boone, Lokshin, Guenter, and Belderbos (2018) found that TMT national diversity has positive effects on corporate entrepreneurship and innovation in multinational corporations but only when TMTs have low social stratification and when a firm's home country is low in cultural power distance.

In line with these findings, there is now a considerable body of work that examines how TMT characteristics interact with one another or serve as moderators of the relationship between CEO orientation and firm outcomes (e.g., Buyl, Boone, \& Hendriks, 2014; Ferguson, Cohen, Burton, \& Beckman, 2015; Heyden et al., 2013; Raes et al., 2011). The work on TMT fault lines-or "conceptual divide[s] that may separate a TMT into subgroups and thus [affect] the structure of diversity within a team" (Hutzschenreuter \& Horstkotte, 2013: 705)—has been especially influential in this regard (e.g., Ling, Wei, Klimoski, \& Wu, 2015; Ou, Seo, Choi, \& Hom, 2016; Richard, Wu, Markoczy, \& Chung, 2019). As an example, Georgakakis, Greve, and Ruigrok (2017) found that different aspects of the CEO-TMT interface have a significant influence on the relationship between TMT knowledge-based fault lines and firm performance. Specifically, they found that CEO-TMT sociodemographic similarity, high CEO career variety, and CEO-TMT shared experience all have a positive moderating influence on this relationship. In an examination of the mediating role of a firm's competitive actions on the resource-performance relationship, Ndofor, Sirmon, and He (2015) found that TMT heterogeneity has a positive effect on the relationship between resources and competitive actions. However, it has a negative effect on the relationship between competitive actions and firm performance. Further, when there 
were strong fault lines within a TMT, all positive effects of TMT heterogeneity were eliminated.

Work has also begun to explore how diversity characteristics-such as gender-may moderate the established relationships between executive orientation and firm outcomes (e.g., Gupta, Han, Mortal, Silveri, \& Turban, 2018; Hoobler, Masterson, Nkomo, \& Michel, 2018; Zhang \& Qu, 2015). For example, Dwivedi, Joshi, and Misangyi (2018) looked at how the characteristics of male CEOs shape their behaviors toward a female successor and, in turn, the new CEO's success. As another example, in a meta-analysis, Jeong and Harrison (2017) found that female representation is positively and weakly related to long-term firm financial performance but negatively and weakly related to short-term stock market returns. The authors found that decreased risk taking is the mediating mechanism that facilitates the positive relationship with financial performance. Several studies also examined the importance of other "diversity" attributes, such as a CEO's socioeconomic status (Kish-Gephart \& Campbell, 2015), ethnicity (Smith, Watkins, Ladge, \& Carlton, 2019), birth order (Campbell, Jeong, \& Graffin, 2019), gender representation (Klein, Chaigneau, \& Devers, in press), or age (Ortiz-de-Mandojana, Bansal, \& Aragon-Correa, 2019). These studies highlight how considering the interaction between executive characteristics can add nuance to our understanding of CEO impact.

Finally, research on discretion has also continued to receive a great deal of attention as a means of understanding variance in UET findings (e.g., Campbell, Campbell, Sirmon, Bierman, \& Tuggle, 2012; Crossland \& Chen, 2013; Graffin, Carpenter, \& Boivie, 2011; Quigley, Hubbard, Ward, \& Graffin, 2020). Notably, Hambrick and Quigley (2014) examined the effect of CEOs on firm performance in subsamples of low- (e.g., steel production), medium - (e.g., hotels), and high - (e.g., computers) discretion industries. They found that CEOs have a significant effect on firm outcomes, that the effect appears to be increasing over time, and that the size of the effect is highly dependent upon the level of discretion within an industry. Relatedly, in a study of diverse manufacturing firms in China, Li and Tang (2010) found that the relationship between CEO hubris and firm risk taking was much stronger when managerial discretion was higher. 
The verdict: Where do we go from here? Our review of the recent UET literature revealed a great deal of progress in understanding how UET results vary depending on a variety of individual, group, organizational, and environmental conditions. More specifically, recent efforts continue to reaffirm the importance of discretion as a key moderating consideration in UET research (e.g., Quigley \& Hambrick, 2012; Wangrow et al., 2015). Additionally, the research demonstrates that executive characteristics (at the individual and TMT levels) often interact in determining the impact of executives on organizational outcomes (e.g., Georgakakis et al., 2017; Mohr \& Batsakis, 2018). Further, ample evidence reinforces the need to consider environmental conditions (e.g., firm conditions, national setting, industry dynamism) in UET research (Belenzon, Patacconi, \& Zarutskie, 2016; Blagoeva, Mom, Jansen, \& George, in press; Boone et al., 2018; Quigley \& Graffin, 2017).

However, despite significant progress, a key limitation remains in that few researchers address-either theoretically or empirically-where in the UET process model such moderators operate. As noted earlier in Conceptual Critiques 1 and 2, executive characteristics are linked to firm outcomes via both cognitive and relational processes. Moderators thus have the potential to operate at several points in this causal chain. The UET studies we examined overwhelmingly used executive characteristic(s) as independent variables, a strategic decision or organizational outcome as the dependent variable, and a moderating variable influencing this relationship. As such, most studies could not identify where key moderating variables operated with respect to mediating cognitive and relational processes (though there are some exceptions, e.g., Boone et al., 2018; Ndofor et al., 2015).

Thus, we propose that a central challenge for UET researchers is shifting from "Do UET results hold across conditions?" or "What contingency factors matter?" to "Where and how do moderating variables operate in the casual chain?" As UET research efforts endeavor to more deliberately outline and investigate cognitive and relational processes, this also creates an opportunity to refine the conceptual underpinnings of the many contingency factors that have been identified in the literature. This increased clarity on the UET process has the potential to enable researchers to make more concrete recommendations that can benefit executives and organizations. 
Methodological Critique 1: (In)congruence of Constructs and Measures

While the UET perspective has garnered tremendous support for its primary propositions (e.g., Bromiley \& Rau, 2016; Finkelstein et al., 2009), there remain fundamental debates regarding the appropriateness of the measures used in this literature and replicability of findings across studies (e.g., Carpenter et al., 2004; Cragun et al., in press; Hodgkinson \& Sparrow, 2002). Recent reviews highlight that UET research is riddled with measures that are poorly justified or validated, and the literature suffers from overall measurement proliferation (e.g., Hambrick, 2007; Wang et al., 2016; Wowak et al., 2017). As such, critics have called for more deliberate approaches to measurement that can inspire greater confidence in study findings and enable more systematic evaluation of UET research overall.

Many of the measurement challenges in UET research stem from the widespread use of proxy variables. Indeed, in their initial presentation of UET, Hambrick and Mason (1984) advocated for the use of demographic variables (e.g., age, tenure, education) as a way to proxy for underlying characteristics of interest (e.g., Hill et al., 2014; Smith et al., 2018). These demographic proxy variables served as a convenient tool for scholars; however, they became a highly critiqued aspect of UET research. A key charge is that demographic proxies (such as age, experience, or tenure) are unreliable and imprecise indicators of underlying psychological characteristics (e.g., Markoczy, 1997; Priem, Lyon, \& Dess, 1999). The use of unvalidated proxies has contributed to inconsistent findings and reduced confidence in causal claims of UET research (Hodgkinson \& Sparrow, 2002; Pettigrew, 1992).

These inconsistencies are exacerbated when proxies are created through the aggregation of group-level (i.e., board or TMT) characteristics because this approach does not account for the factors (e.g., group member functional roles, group processes, and differences between CEO and group member characteristics) that influence each individual's contribution to group decision making (Carpenter et al., 2004; Jensen \& Zajac, 2004; Pettigrew, 1992). Recent research shows that decisions regarding the way we aggregate variables (e.g., average, ratio, index) in group-level UET work indeed has important implications for research findings (Carpenter et al., 2004; Colbert, Barrick, \& Bradley, 2014; Tuttle, Schnatterly, \& Johnson, 2010). Yet aggregation approaches across the 
management literature (UET research is no exception) typically lack a strong conceptual foundation-for example, are TMT outcomes really a function of shared team tasks? Or are they simply treated as "team" outcomes because it is difficult to observe individual accountability? In the absence of such justifications, aggregated variables make it hard to know what mechanisms account for observed relationships with firmlevel outcomes (Beckman \& Burton, 2011; Carpenter et al., 2004; Hambrick, 2007).

Critiques of individual- and team-level proxy variables have evolved over time. The reliance on demographic proxies has declined as researchers have begun to use other unobtrusive measures of executive traits (e.g., the size of a CEO's picture as a measure of narcissism; Chatterjee \& Hambrick, 2007). Indeed in current conversation, "proxy variables" refers no longer exclusively to demographic measures but rather to any measure of executive personality, cognition, values, and so on that is not based on self-report. While criticisms highlight common limitations across all of these measures, a more nuanced discussion has emerged that focuses on whether such measures have been appropriately validated as measures of the constructs they are said to represent (Carpenter et al., 2004; Hodgkinson \& Sparrow, 2002; Lawrence, 1997; Wang et al., 2016). That is, reviewers contend that even if self-report or other forms of direct measurement are not feasible for this population, indirect measures can still be subjected to validation procedures. Thus, over the years, reviews have called for UET efforts both to move beyond demographic proxies when possible (Carpenter et al., 2004; Hiller et al., 2011; Wowak et al., 2017) and to better justify the use of proxy measures, including how these measures are aggregated at the group level (e.g., Carpenter et al., 2004; Lawrence, 1997).

Review of recent progress. Over the past 10 years, there has been a notable increase in studies of top executives that use more direct measurement techniques (e.g., through surveys and interviews) to examine executives' underlying characteristics (e.g., Colbert et al., 2014; Heavey \& Simsek, 2017; Herrmann \& Nadkarni, 2014). As an example, Booth and colleagues (2016) had executives from the United Kingdom complete a psychometric assessment of personality and cognitive ability to examine how these characteristics relate to the career paths that differentiate CEOs from other senior management members. The authors found 
that there was significant variation in a number of individual differences between the CEO and senior management groups.

In our review, we also observed a surge of studies that utilize direct approaches to measure group-level characteristics (i.e., survey or interview; e.g., Buyl, Boone, Hendriks, \& Matthyssens, 2011; Clark \& Maggitti, 2012; Raes et al., 2011). In doing so, many of these studies obtained confirmation from CEOs and their organizations regarding the individuals that should be included in TMTs and boards, ensuring the relevance of their individual input to group-level variables (e.g., Colbert et al., 2014; Friedman, Carmeli, \& Tishler, 2016). Further, many of these studies (e.g., Hartnell, Kinicki, Lambert, Fugate, \& Corner, 2016; Mannor, Matta, Block, Steinbach, \& Davis, 2019; Qian et al., 2013) rely on established methodological approaches from other organizational research areas to defend the appropriateness of the aggregation of group-level variables (see Bliese, 2000; Woehr, Loignon, Schmidt, Loughry, \& Ohland, 2015). Thus, while direct measurement of executive characteristics remains challenging, there appears to be growing success in finding study contexts in which such techniques are indeed feasible.

Second, we also observe that researchers are doing more to conceptually justify the relationship of unobtrusive measures to the constructs they are intended to represent (Schubert \& Tavassoli, 2020; Wowak et al., 2016). As an example, Crossland and colleagues (2014) provide a detailed explanation for their study of CEO career variety on firm strategic and social novelty. Not only do they conceptually justify the relationship of their measure with several outcomes of interest, but they also outline how career variety overlaps with underlying individual differences (e.g., openness, risk propensity, neuroticism, need for autonomy, cognitive breadth). The authors use this overlap to justify why career variety is a strong proxy for unobservable motivations and cognitions. In their examination of the impact of TMT misfit on TMT composition and structure, Ferguson, Cohen, Burton, and Beckman 2015 provide a clear and concise explanation of why their conceptualization of TMT misfit required a measure that met several important conditions, including being able to assess misfit across the entire team (i.e., not just as an aggregation of individual-level misfit). Additionally, they ran robustness checks to provide greater transparency regarding the nature of their measurement approach and its impact on the study's findings, detailing the conceptual differences with the approach of their primary analysis. 
Third, many recent studies have stressed the importance of validating the unobtrusive measures they develop or of relying on measures previously validated by other studies (e.g., Chen, Crossland, \& Luo, 2015; Hill, Kern, \& White, 2012). One example of a study that validated a new measurement technique is that of Petrenko, Aime, Ridge, and Hill (2016). They went through an extensive validation process to support the use of a "videometric" approach to examine CEO narcissism and its influence on a firm's engagement in corporate social responsibility (for additional refinement of this validation process, see Petrenko, O. V., Aime, F., Recendes, T., \& Chandler, 2019). Building on previous work (e.g., Gamache, McNamara, Mannor, \& Johnson, 2015; Malhotra, Morgan, \& Zhu, 2018) that used literary analysis as a means of unobtrusively assessing executive characteristics, Harrison and colleagues (2019) conducted an extensive validation of executive personality traits (i.e., the Big Five) using machine-learning algorithms. Specifically, they compared personality assessments from CEO speech transcripts to scores on a direct, psychometrically validated measure of the same construct. In doing so, they were able to validate their measure and convincingly relate executive personality to strategic change and firm performance. Of note, these studies highlight an increasingly common practice of cross-validating new measures (see Gamache et al., 2015; Harrison et al., 2019; Petrenko et al., 2016), helping to address the lack of convergence of certain measures in UET research (Chen et al., 2015).

The verdict: Where do we go from here? Overall, our review confirms that the UET literature has taken steps to achieve better congruence between empirical measures and the constructs they are intended to represent. In particular, the field has acknowledged the limitations of proxy variables (demographic ones as well as others) when attempting to broadly infer underlying executive traits or characteristics at the individual and group levels (Hambrick, 2007; Lawrence, 1997). As a consequence, we observed significant progress in the use of direct measurement approaches, conceptual justifications offered for demographic proxy measures (where they are still used), techniques utilized to justify aggregation approaches, and validation procedures for new unobtrusive measures (e.g., Crossland, Zyung, Hiller, \& Hambrick, 2014; Harrison et al., 2019). To further capitalize on this progress, we recommend that researchers and reviewers approach measurement with new expectations and standards in mind. 
First, we posit that the central issue confronting UET researchers is no longer whether proxy variables should or should not be used. It is important to remember that essentially all measures are "proxies" to varying degrees, including self-report survey instruments. Such instruments are a closer, yet still somewhat indirect, measure of underlying psychological or cognitive constructs and, consequently, remain subject to "noise," such as social desirability response bias or self-report bias (e.g., Dalton \& Ortegren, 2011; Donaldson \& Grant-Vallone, in press; Moorman \& Podsakoff, 1992). Indeed, it may even be the case that we need to stop thinking narrowly about self-reports as the "gold standard" for capturing the "inner workings" of executives. Individuals may engage in deception or impression management when responding to surveys or, even with the best of intentions, may not always accurately judge themselves. For example, Oh, Wang, and Mount (2011) demonstrated in a meta-analysis of 18 independent samples that acquaintance ratings on Big Five personality traits were more predictive of overall employee job performance than self-reports. Other-reports also proved incrementally predictive of job performance above and beyond self-reports. This suggests that the small body of UET research examining other-reports should not only continue but expand (e.g., Heavey \& Simsek, 2017; Mannor et al., 2016). Information provided by alternate sources, such as administrative assistants, spouses, or direct reports, may provide unique, valid, and useful perspectives not just in the absence of self-reports but potentially in place of or in addition to them.

Next, at the group level, evidence of conceptual justification of aggregation techniques, more direct measures of group member characteristics, and the reliance on well-established methodological approaches to aggregation all indicate that the field is addressing previous critiques. With this progress in mind, a number of important questions remain. For example, are typical team aggregation approaches appropriate for groups at the upper echelon of organizations? Do these methods account for what we have learned about functional roles of TMT members or TMT fault lines in recent literature? Indeed, these (and other) questions are just one aspect of a much larger discussion surrounding the appropriate approaches to the examination of TMT and board structure and composition (Beckman \& Burton, 2011; Menz, 2012). Given the volume of studies focused on group-level UET phenomena and the methodological improvements we observed in our review, we propose that this 
broader discussion warrants its own updated and focused review. A willing scholar might use the numerous research opportunities presented in Menz (2012) as a starting point to review the progress made on understanding the advancement of group-level phenomena in UET research.

In sum, UET researchers should no longer focus on blanket statements about measurement appropriateness, instead considering more nuanced questions, such as the following: How distal is the measure from what it claims to represent? How persuasive is the justification offered for this relationship? The more distal a measure is from the construct it is said to represent, the more must be done to establish the validity of the measure. If UET researchers can build a stockpile of validated measures, doing so would significantly advance the science of the field by enabling greater consistency in measurement techniques and allowing for easier comparison of results. Researchers could then delve into more complex analyses while controlling for factors already known to be important. Ultimately, UET scholars must provide evidence for the appropriateness of whatever measure they use, defend their approach to the aggregation of variables at the group level, understand that every measure has limitations, and acknowledge that multiple methods for measuring underlying constructs (both within and across studies) engender greater confidence in research findings (as UET examples, see Harrison et al., 2019; Hill et al., 2014; Petrenko et al., 2016).

\section{Methodological Critique 2: Need for Increased Attention to Endogeneity}

The reviews we examined consistently raised questions about the ability of existing UET research to properly delineate causality (e.g., Carpenter et al., 2004; Hoskisson et al., 2017; Hutzschenreuter et al., 2012). For example, since executives are not randomly assigned to their organizations, there is the possibility that rather than executive orientation influencing decision making, the observed relationships are caused by organizational outcomes or environmental factors, influencing the profiles of the executives that are selected to lead in certain strategic situations (Finkelstein et al., 2009; Hambrick, 2005, 2007). This is one variety of endogeneity that is often referenced and threatens the ability of researchers to draw accurate causal inferences (e.g., Antonakis, Bendahan, Jacquart, \& Lalive, 2010; Certo, Busenbark, Woo, \& Semadeni, 2016; Hamilton \& Nickerson, 2003). Of course, this threat, and the need 
to more deliberately address it, is not isolated to UET research (Wolfolds \& Siegel, 2019). Multiple articles highlight the widespread mismanagement of endogeneity concerns across the strategic management and leadership literatures (e.g., Antonakis et al., 2010; Bliese, Schepker, Essman, \& Ployhart, in press). A key challenge, however, is that endogeneity, and the terminology used to discuss it, is not consistent across UET reviews or research articles. Thus, we found that there were significant barriers to understanding endogeneity critiques in ways that made both the empirical problems and solutions clear to readers.

"Endogeneity exists when the independent variable in a study is correlated with the error term (also known as 'disturbance' or 'residual') in an ordinary least squares regression" (Semadeni, Withers, \& Certo, 2014: 1070). If left unchecked or mismanaged, endogeneity can bias the findings and interpretations of nonexperimental empirical investigations. As a result, researchers may inappropriately attribute causality, identify relationships that do not exist, or fail to identify important relationships that do exist. Endogeneity can originate from several sources (Antonakis et al., 2010). Three that are particularly relevant to the UET research stream are (a) the omission of variables (i.e., unobserved heterogeneity due to selection bias or failure to include an important control), (b) measurement error in variables (e.g., using an unreliable measure of the independent variable and not modeling measurement error), and (c) reverse/simultaneous causality (Antonakis et al., 2010; Semadeni et al., 2014). We found that researchers and reviewers often misunderstood that all of these factors can create endogeneity concerns; as a result, they often used "endogeneity" interchangeably with terms such as "reverse causality" or "selection bias."

This is problematic as there are also a variety of techniques to empirically address endogeneity including two-stage least squares (2SLS) estimation (Semadeni et al., 2014) propensity score analysis (PSA; Love, Lim, \& Bednar, 2017), and Heckman models (Zhu \& Shen, 2016). Which of these techniques is most appropriate ultimately depends on the specific source(s) of endogeneity that threaten a study's findings. This puts an onus on researchers not only to recognize potential endogeneity threats but to appropriately match their empirical solution to the specific nature of the problem (for more comprehensive methodological guidance, see Antonakis et al., 2010; Bliese et al., in press; Certo et al., 2016; Semadeni et al., 2014; Wolfolds \& Siegel, 2019). Failure to do 
so often raises questions about the causal attributions that can be supported by a study's findings.

Review of recent progress. Hambrick (2007: 338) argued that the need to address endogeneity in UET research is not a "technical nicety but, instead, is essential for gaining a grasp of the causal mechanisms that lie behind empirical associations." We identified important trends in the UET research stream related to endogeneity. First, while UET studies are utilizing a wider variety of research methods, most of the empirical efforts in our sample remain susceptible to endogeneity (i.e., use nonexperimental designs). Second, the vast majority of UET empirical articles with potential endogeneity concerns do (a) identify it as an issue and (b) describe how they aimed to address this threat to their empirical findings. Third, while recognition of endogeneity is now widespread, we noted significant variance in whether the specific source(s) of endogeneity was identified and used to justify the selection of a particular empirical technique (e.g., 2SLS, PSA, Heckman models, time-lagged variables). There was also inconsistent use of analyses designed to establish the presence of endogeneity before proceeding to solutions (Antonakis et al., 2010; Semadeni et al., 2014).

Several articles in our sample stand out for how they addressed endogeneity. In their investigation of the connection between CEO narcissism and firm outcomes, for example, Chatterjee and Hambrick (2011) clearly explain the potential sources of endogeneity in their study (e.g., CEOs selecting into certain situations), report the results of the tests they use to determine whether endogeneity threats exist, and detail the development of the instruments used in their subsequent empirical tests. As another example, Kish-Gephart and Campbell (2014) not only explain the potential sources of endogeneity in their study of CEO social class and strategic risk taking but also offer a robust discussion that includes a justification of their approach to managing endogeneity, an explanation of the standards for sound instruments, a report on the strength and validity of their instruments, and a test of instrument exogeneity. Additionally, Gamache and colleagues (2019) lay out a useful blueprint for addressing potential endogeneity in their examination of CEO signaling motives underlying strategic actions. In their supplemental analysis, after identifying the potential endogeneity threat (omitted variable), they lay out the multiple steps taken to address the issue (two-stage residual inclusion tobit model and test for impact threshold 
of a confounding variable). There are several other useful examples of studies that have likewise endeavored to identify and mitigate endogeneity threats in their empirical efforts (e.g., Schubert \& Tavassoli, 2020; Wong, Ormiston, \& Tetlock, 2011).

The verdict: Where do we go from here? Overall, the UET literature has made significant progress in its attempts to more deliberately establish causality by addressing endogeneity concerns. At a minimum, there is now widespread awareness of the endogeneity critiques raised by previous reviews and evidence that scholars are taking steps to establish greater confidence in the causal inferences being drawn from UET studies. However, we observed tremendous variability in the quality of the explanations of potential sources of endogeneity and in the appropriateness of the techniques utilized to address it. There is a need for greater consistency in how endogeneity is discussed, empirically tested, and empirically remedied in UET research so that researchers, reviewers, and readers can better evaluate study results and communicate causal inferences. In addition, scholars should also look for more opportunities to utilize experimental designs, perhaps alongside the use of archival data, to more directly substantiate their theorized causal mechanisms.

First, given the prominence of endogeneity concerns in UET research, all empirical studies should indicate why specific endogeneity threats are, or are not, a concern given their methodological design and data sources. Too often research focuses on only one or two endogeneity concerns when multiple threats exist. If endogeneity is a potential threat, researchers must clearly identify the source of that threat(s) (e.g., unobserved heterogeneity, measurement error, simultaneous causality; Antonakis et al., 2010; Semadeni et al., 2014). Next, appropriate tests should be used to determine and report whether these potential threats are indeed creating actual problems with the data; analyses designed for this purpose are well explained elsewhere in the strategic management literature (Certo et al., 2016; Wolfolds \& Siegel, 2019). If endogeneity is present, researchers should then explain the approach they use to address it and detail why that approach (e.g., 2SLS, PSA, Heckman models) is appropriate (Antonakis et al., 2010; Semadeni et al., 2014).

Rather than addressing endogeneity in a post hoc fashion through statistical and analytical means, UET scholars might also consider making greater use of alternative research designs that are less subject to 
specific forms of endogeneity. In contrast to archival or survey-based designs, experiments randomly assign participants into study conditions (i.e., treatment and control group), ensuring that any change observed in the dependent variable is a result of the manipulation in the study (Antonakis et al., 2010; Rubin, 2008). As such, these efforts are able to confidently make causal inferences from their results. While randomized field experiments are the "gold standard" (Antonakis et al., 2010: 1088), we acknowledge that it can be difficult to convince organizations to participate in such experiments. Nevertheless, researchers have had success with this approach by targeting smaller, private firms (for helpful examples, see Chatterji, Delecourt, Hasan, \& Koning, 2019; Hasan \& Koning, 2019). Recent studies also highlight that even online, survey-based experiments may be appropriate for UET studies that seek to understand the perceptions of stakeholder groups, such as investors or customers (Connelly, Haynes, Tihanyi, Gamache, \& Devers, 2016; Cowen \& Montgomery, 2020; Krause, Whitler, \& Semadeni, 2014). These designs could play a role in, say, studies that examine CEOs' interfaces with more distal stakeholders, as highlighted in Conceptual Critique 2. A final possibility is to supplement archival data with targeted experiments that can better isolate theorized mechanisms. Such experiments could be conducted with more readily accessible samples of managers, such as executive education participants or MBA students. There are a handful of recent UET studies that have utilized mixed-methods approaches (e.g., Jung \& Shin, 2018; Souitaris, Zerbinati, Peng, \& Shepherd, 2020) to leverage the benefits of different research designs. This approach could be an effective way for scholars to respond to endogeneity concerns while also making progress in teasing out important mediators (e.g., Aguinis \& Solarino, 2019; Tunarosa \& Glynn, 2017).

\section{Leveraging Verdicts for Future Impact}

In this review, we synthesize and evaluate metacritiques of UET research in an effort to develop a common understanding of issues of significant and repeated concern and to provide scholars with clear recommendations for future work. Our discussion of these metacritiques is not intended to simply to offer research questions for future study; rather, this approach fundamentally aims to advance more consistent 
standards for how all UET research should be conducted. We hope that the idea of examining metacritiques might also be extended to other literatures facing similar challenges. In particular, we proposed at the outset that the time was right for such an endeavor in the UET literature for two, interrelated reasons. The first concerns research trajectory-there has been a significant increase in UET research over the past decade (e.g., Gupta et al., 2018; Wowak et al., 2016), which has led the domain to simultaneously expand and become more specialized. The second reason was phenomenological. As executives guide their organizations through a rapidly changing and globalized world, the impact of executives (and their individual idiosyncrasies) is likely to continue to expand (e.g., Hambrick \& Quigley, 2014; Quigley, Crossland, \& Campbell, 2017; Quigley \& Graffin, 2017), and the conceptual and methodological issues we tackle in this review are, consequently, taking on new significance for UET scholars.

From the explosion of social media to the unstable global economic and political landscape to fundamental questions now being raised about business organizations and their role in society, the world in which strategic leaders operate is both changing and becoming increasingly complex. Such complex and shifting conditions raise new and interesting questions about how leaders conceptualize their (and their organizations') appropriate role and influence, how they interface with more distal stakeholders (e.g., customers), and what impact such choices may have on not only organizational outcomes but societal or political ones. Cognition, relationships, and context inherently lie at the heart of all of these issues. As such, our review is also timed to help better position scholars to capitalize on the UET research platform to study executives across their growing sphere of influence.

We now return to this review's phenomenological motivation and take stock of how our contributions might help UET research to embrace the task of providing insight into these dynamic challenges moving forward. We do not intend to be exhaustive in our discussion of potential research streams. Instead, our goal is to highlight how the issues we have addressed in this review will help increase the ability of researchers to respond to important emerging phenomena for executives and to do so in ways that can increase the credibility and impact of UET's contributions. 


\section{Broadening Influence Beyond the Business Domain}

In the summer of 2018 , news broke of family separations taking place at the U.S.-Mexico border. Uber CEO Dara Khosrowshahi, who immigrated to the United States from Iran as a child, quickly spoke out on social media against the Trump administration's policies (Price, 2018; Stillman, 2018). He also mobilized company resources to respond to this situation - pledging $\$ 100,000$ to a legal defense fund for immigrant children, sending Uber's legal team to help reunite families, and urging employees to take individual action (Stillman, 2018). Instances of "CEO activism" are increasingly common (Chatterji \& Toffel, 2018; Dolan, 2019). Executives are weighing in on hot-button issues either because their organizations are unexpectedly caught in a media firestorm (e.g., CEO Kevin Johnson following the arrest of two African American men at a Starbucks in Philadelphia; Mark Zuckerberg in the wake of the Facebook-Cambridge Analytica data scandal) or because they are deliberately choosing to use the organization as a platform to express social or political opinion (e.g., Qantas's support of legislation to allow samesex marriage in Australia, Disney's stance on abortion laws in the U.S. state of Georgia). For both reasons, we observe organizations and their leaders being increasingly drawn into social and political issues that often extend beyond the core mission of an organization or how the literature has traditionally studied corporate social responsibility (CSR). Additional exploration of this phenomenon is important given the potential risks and rewards executives and firms may incur from speaking out in these situations (Hambrick \& Wowak, in press; Mayer, 2017).

UET stands to play an important role in offering insight into how executive orientation shapes leaders' actions in these situations-personally and organizationally-as well as what consequences their decisions have for both firm performance and outcomes outside the firm (e.g., public opinion, government policies, analyst response; Hambrick \& Wowak, in press; Wowak et al., 2016). Thus, these topics have begun to garner greater research attention (e.g., Christensen, Dhaliwal, Boivie, \& Graffin, 2015; Graffin, Hubbard, Christensen; \& Lee, in press; Gupta \& Wowak, 2017). As an example, Chin, Hambrick, and Trevino (2013) used 10 years' worth of publicly available records on CEO political donations to illustrate how CEOs' political ideologies shape firms' approaches to CSR activities. Briscoe, Chin, and Hambrick (2014) considered how executive 
political ideology (conservatism vs. liberalism) influenced the likelihood of employee activism under a variety of conditions. These findings and others (e.g., Gupta et al., 2017; Maak, Pless, \& Voegtlin, 2016) demonstrate that UET scholars can offer meaningful insight on how strategic leaders navigate the social and political environment.

However, engagement with social and political issues is intimately tied to executive cognition and, specifically, to questions regarding how leaders construe their identity, their role as CEO, their moral obligations to stakeholders (Maak et al., 2016), and the legitimate domains of organizational activity. While some of these factors may have less relevance to the outcomes the literature has typically investigated (e.g., risk taking, acquisition decisions), they, too, speak to the need to devote greater attention to unpacking the cognitive black box in UET research. Indeed, we believe that more explicit investigation of the information-filtering process, and its connection to executive orientation, will be essential if scholars are to better understand the choices executives make regarding activism. Questions that future UET research can explore include the following: Under what conditions do executives decide to act personally versus organizationally? How might executives' personal opinions interact with their views of role obligations in reaching those decisions? How or when do executives frame social issues as related to organizational performance versus part of a broader role that organizations should play in society? In what ways might an executive's background affect their attention, perception, and interpretation of information when confronting such issues?

Devoting attention to contingency factors-an issue highlighted in our third critique - also has relevance to advancing research on CEO activism. There is already evidence that CEOs' engagement with charged issues is of concern to both boards and shareholders (DuBois, 2012). Thus, it would be useful to understand how they might manage such behaviors through executive selection, compensation, or governance practices. Well-established moderators may also yield new insights in this context. For example, to what extent does the concept of discretion also apply to executives' ability to engage in sociopolitical spheres? In short, by capitalizing on the recommendations offered earlier (i.e., in our first and third conceptual critiques), UET scholars can increase the impact of their work on activism and the increasingly visible role of organizations in social and political controversies. 
Shrinking Distance of "Distal" Relationships

In 2017, a passenger on a United flight from Chicago to Louisville was infamously dragged out of his seat when the flight was overbooked (Goldstein, 2017). The incident went viral and was compounded by United CEO Oscar Munoz's response, in which he apologized for having to reaccommodate the customer and then blamed the passenger for what had occurred. Other customers were outraged by the tone deafness of the statement and their angry responses later made headlines of their own. Beyond the media firestorm, the company's market value was down as much as a billion dollars in the immediate aftermath of the incident (Reklaitis, 2017). This illustrated the consequences of how technology is shrinking the distance between executives and traditionally more "distal" stakeholder groups, like customers (as noted in Conceptual Critique 2). Indeed, many CEOs now routinely use social media platforms to engage in conversation with stakeholders, like customers and lower-level employees, with whom they would have had few interactions in earlier periods.

The increased visibility and accessibility of executives presents unique opportunities for UET research. Scholars have long viewed managing the boundaries between the organization and its external environment as a primary role of executives (e.g., Finkelstein et al., 2009; Mintzberg, 1973). However, the modern age of media has fundamentally changed these boundaries-the demarcations between organizations and their environments are more permeable than ever (Kim \& Youm, 2017). As such, an executive's actions have the potential to reach further and carry greater meaning to a wider variety of stakeholders. At the same time, these once-distal groups are increasingly able to exert their influence on executives, as well (Pfarrer et al., 2019; Steinbach et al., 2019). Recent research highlights the importance of better understanding these relational processes between executives and external stakeholders (e.g., the media, analysts, investors, external peer executives; Gamache \& McNamara, 2019; Konig et al., in press; Westphal et al., 2012). Although UET has more commonly focused on interfaces between CEOs and TMTs, this work nevertheless provides a platform that could be extended to now study CEOs' interactions with more distal stakeholder groups. 
However, as we noted in our second conceptual critique, for this work to have impact with practicing managers, it must observe such relationships more directly-capturing not just characteristics of the actors but their behaviors and communications. Access to relevant data on these interfaces is increasingly available as CEOs' interactions with customers and employees often take place in more accessible forums. In particular, the use of publicly facing social media platforms, such as Facebook and Twitter, create promising avenues to collect rich data that permit unobtrusive measurement of executive characteristics, actions, and communications with various stakeholders (e.g., Hill et al., 2014; Park et al., 2015). As such, there are a variety of interesting questions that UET scholars could investigate. For example, how do CEOs' characteristics influence how their online communications are judged by external audiences? Do executives that communicate regularly online (e.g., Elon Musk of Tesla, John Legere of T-Mobile) enjoy higher reputation or trust with stakeholder groups? How do audience reactions (e.g., employees, customers, analysts) in the wake of high-stakes communications (e.g., following a crisis), in turn, influence executive decision making and action?

Further, in line with our third conceptual critique, there are a host of contingency factors that also have the potential to influence the relational process between executives and external stakeholders. As an example, Gomulya, Wong, Ormiston, and Boeker (2017) recently illustrated that something as simple as the trustworthy facial features of a CEO can garner more positive reactions from external observers following a fraud incident. Do such visual cues (e.g., video statements) moderate how CEOs' communications affect stakeholder groups? More broadly, how do well-established factors in the UET literature, like CEO reputation or celebrity, influence these relational processes? In short, through further exploration of the relational mechanisms through which executives and more distal stakeholders (e.g., customers, the media, analysts) influence one another, UET scholars can provide insight on new stakeholder interfaces, which many leaders are struggling to manage effectively.

\section{Toward Greater Confidence and Impact}

There are vigorous debates taking place in the social sciences that fundamentally call into question the credibility and trustworthiness of 
academic scholarship. While a full review of the issues surrounding this crisis of confidence is beyond the scope of this review (for thorough commentaries, see Aguinis et al., 2018; Bettis, Ethiraj, Gambardella, Helfat, \& Mitchell, 2016; Pashler \& Wagenmakers, 2012; Rynes et al., 2018), it is fair to say that scholars are now faced with an environment that is increasingly skeptical of the results and inferences presented in their work. Management scholars who have commented on this trend have stressed the need for rigorous analyses in line with best practices and for improved transparency in the conceptual and methodological approaches on which our studies are founded (e.g., Bettis et al., 2016; Schwab \& Starbuck, 2017; Wigboldus \& Dotsch, 2016).

Our verdicts speak directly to how such broad recommendations can be implemented in the UET domain, positioning UET scholars to be a part of the solution in (re)establishing the credibility of management research. Our conceptual verdicts focus on building confidence in UET work by calling for more detailed theorizing about the cognitive and relational processes that underlie our predictions and coupling this with more accurate data on cognition (i.e., other-reports) and relationships (e.g., qualitative studies). We also urge scholars to be more transparent in specifying where in the causal process moderators are operating so that readers can better understand the implications of such contingencies. Our methodological verdicts provide concrete suggestions for the standards that should guide the use of proxy variables and their aggregation at the group level, which include both more solid theoretical grounding as well as empirical justification. We also provide resources for scholars to use in understanding both how to address endogeneity and how to communicate this work to readers in a transparent fashion.

Scholars must consistently devote attention to the real-world applicability of their research (Davis, 2015; Judge, 2019). UET research has great potential to contribute to real-world outcomes, but that fulfillment of this potential will require more focused efforts to communicate the utility and credibility of our research findings. It is essential for UET scholars to keep pace with the challenges relevant to strategic leaders today and to produce research findings that inspire confidence in the validity of our inferences. Thus, our recommendations are intended to aid future research efforts and, ultimately, to facilitate research that has impact for leaders and their organizations. 
Acknowledgments The first two authors contributed equally to this article. We would like to thank editor Gerard Hodgkinson and two anonymous reviewers for their invaluable feedback and guidance during the review process. This research was supported by the MacGill Quasi Endowment Fund and the McIntire School of Commerce.

\section{References}

Abatecola, G., Caputo, A., \& Cristofaro, M. 2018. Reviewing cognitive distortions in managerial decision making: Toward an integrative co-evolutionary framework. Journal of Management Development, 37: 409-424.

Aguinis, H., Ramani, R. S., \& Alabduljader, N. 2018. What you see is what you get? Enhancing methodological transparency in management research. Academy of Management Annals, 12: 83-110.

Aguinis, H., \& Solarino, A. M. 2019. Transparency and replicability in qualitative research: The case of interviews with elite informants. Strategic Management Journal, 40: 1291-1315.

Antonakis, J., Bendahan, S., Jacquart, P., \& Lalive, R. 2010. On making causal claims: A review and recommendations. Leadership Quarterly, 21: 1086-1120.

Bao, S., Fainshmidt, S., Nair, A., \& Vracheva, V. 2014. Women in upper echelons of management, tenure and legal risk. British Journal of Management, 25: 388-405.

Beckman, C. M., \& Burton, M. D. 2011. Bringing organizational demography back in: Time, change and structure in top management team research. In M. A. Carpenter (Ed.), Handbook of top management team research: 49-70. Cheltenham, UK: Edward Elgar.

Belenzon, S., Patacconi, A., \& Zarutskie, R. 2016. Married to the firm? A large-scale investigation of the social context of ownership: A large-scale investigation of the social context of ownership. Strategic Management Journal, 37: 2611-2638.

Benischke, M. H., Martin, G. P., \& Glaser, L. 2019. CEO equity risk bearing and strategic risk taking: The moderating effect of CEO personality. Strategic Management Journal, 40: 153-177.

Bettis, R. A., Ethiraj, S., Gambardella, A., Helfat, C., \& Mitchell, W. 2016. Creating repeatable cumulative knowledge in strategic management: A call for a broad and deep conversation among authors, referees, and editors. Strategic Management Journal, 37: 257-261.

Bilgili, T. V., Calderon, C. J., Allen, D. G., \& Kedia, B. L. 2017. Gone with the wind: A meta-analytic review of executive turnover, its antecedents, and postacquisition performance. Journal of Management, 43: 1966-1997.

Blagoeva, R., Mom, T. J., Jansen, J. J., \& George, G. in press. Problem-solving or selfenhancement? A power perspective on how CEOs affect R\&D search in the face of inconsistent feedback. Academy of Management Journal. https://doi. org/10.5465/amj.2017.0999

Bliese, P. D. 2000. Within-group agreement, non-independence, and reliability: Implications for data aggregation and analysis. In K.J. Klein and S.W. Kozlowski (Eds.), Multilevel theory, research, and methods in organizations: Foundations, extensions, and new directions: 349-381. San Francisco: Jossey-Bass. 
Bluedorn, A. C., Johnson, R. A., Cartwright, D. K., \& Barringer, B. R. 1994. The interface and convergence of the strategic management and organizational environment domains. Journal of Management, 20: 62.

Boivie, S., Graffin, S. D., \& Pollock, T. G. 2012. Time for me to fly: Predicting director exit at large firms. Academy of Management Journal, 55: 1334-1359.

Bono, J. E., \& Ilies, R. 2006. Charisma, positive emotions and mood contagion. Leadership Quarterly, 17: 317-334.

Boone, C., Lokshin, B., Guenter, H., \& Belderbos, R. 2018. Top management team nationality diversity, corporate entrepreneurship, and innovation in multinational firms. Strategic Management Journal, 40: 277-302.

Booth, T., Murray, A. L., Overduin, M., Matthews, M., \& Furnham, A. 2016. Distinguishing CEOs from top level management: A profile analysis of individual differences, career paths and demographics. Journal of Business and Psychology, 31: 205-216.

Briscoe, F., Chin, M. K., \& Hambrick, D. C. 2014. CEO ideology as an element of the corporate opportunity structure for social activists. Academy of Management Journal, 57: 1786-1809.

Bromiley, P., \& Rau, D. 2016. Social, behavioral, and cognitive influences on upper echelons during strategy process: A literature review. Journal of Management, 42: 174-202.

Busenbark, J. R., Krause, R., Boivie, S., \& Graffin, S. D. 2016. Toward a configurational perspective on the CEO: A review and synthesis of the management literature. Journal of Management, 42: 234-268.

Butler, M. J., O’Broin, H. L., Lee, N., \& Senior, C. 2016. How organizational cognitive neuroscience can deepen understanding of managerial decision-making: A review of the recent literature and future directions. International Journal of Management Reviews, 18: 542-559.

Buyl, T., Boone, C., \& Hendriks, W. 2014. Top management team members' decision influence and cooperative behaviour: An empirical study in the information technology industry. British Journal of Management, 25: 285-304.

Buyl, T., Boone, C., Hendriks, W., \& Matthyssens, P. 2011. Top management team functional diversity and firm performance: The moderating role of CEO characteristics. Journal of Management Studies, 48: 151-177.

Campbell, J. T., Campbell, T. C., Sirmon, D. G., Bierman, L., \& Tuggle, C. S. 2012. Shareholder influence over director nomination via proxy access: Implications for agency conflict and stakeholder value. Strategic Management Journal, 33: 1431-1451.

Campbell, R. J., Jeong, S.-H., \& Graffin, S. D. 2019. Born to take risk? The effect of CEO birth order on strategic risk taking. Academy of Management Journal, 62: 1278-1306.

Carmeli, A., Schaubroeck, J., \& Tishler, A. 2011. How CEO empowering leadership shapes top management team processes: Implications for firm performance. Leadership Quarterly, 22: 399-411.

Carpenter, M. A., Geletkanycz, M. A., \& Sanders, Wm. G. 2004. Upper echelons research revisited: Antecedents, elements, and consequences of top management team composition. Journal of Management, 30: 749-778. 
Certo, S. T., Busenbark, J. R., Woo, H., \& Semadeni, M. 2016. Sample selection bias and Heckman models in strategic management research. Strategic Management Journal, 37: 2639-2657.

Chatterjee, A., \& Hambrick, D. C. 2007. It's all about me: Narcissistic chief executive officers and their effects on company strategy and performance. Administrative Science Quarterly, 52: 351-386.

Chatterjee, A., \& Hambrick, D. C. 2011. Executive personality, capability cues, and risk taking: How narcissistic CEOs react to their successes and stumbles. Administrative Science Quarterly, 56: 202-237.

Chatterji, A., Delecourt, S., Hasan, S., \& Koning, R. 2019. When does advice impact startup performance? Strategic Management Journal, 40: 331-356.

Chatterji, A., \& Toffel, M. 2018. The new CEO activists. Harvard Business Review, 96: 78-89.

Chen, G., Crossland, C., \& Luo, S. 2015. Making the same mistake all over again: CEO overconfidence and corporate resistance to corrective feedback. Strategic Management Journal, 36: 1513-1535.

Chen, J., \& Nadkarni, S. 2017. It's about time! CEOs' temporal dispositions, temporal leadership, and corporate entrepreneurship. Administrative Science Quarterly, 62: 31-66.

Chen, M.-J., \& Miller, D. 2012. Competitive dynamics: Themes, trends, and a prospective research platform. Academy of Management Annals, 6: 135-210.

Chin, M. K., Hambrick, D. C., \& Trevino, L. K. 2013. Political ideologies of CEOs: The influence of executives' values on corporate social responsibility. Administrative Science Quarterly, 58: 197-232.

Christensen, D. M., Dhaliwal, D. S., Boivie, S., \& Graffin, S. D. 2015. Top management conservatism and corporate risk strategies: Evidence from managers' personal political orientation and corporate tax avoidance. Strategic Management Journal, 36: 1918-1938.

Clark, K. D., \& Maggitti, P. G. 2012. TMT potency and strategic decision-making in high technology firms. Journal of Management Studies, 49: 1168-1193.

Colbert, A. E., Barrick, M. R., \& Bradley, B. H. 2014. Personality and leadership composition in top management teams: Implications for organizational effectiveness. Personnel Psychology, 67: 351-387.

Combe, I. A., \& Carrington, D. J. 2015. Leaders' sensemaking under crises: Emerging cognitive consensus over time within management teams. Leadership Quarterly, 26: 307-322.

Connelly, B. L., Haynes, K. T., Tihanyi, L., Gamache, D. L., \& Devers, C. E. 2016. Minding the gap: Antecedents and consequences of top management-to-worker pay dispersion. Journal of Management, 42: 862-885.

Connelly, M. S., Gilbert, J. A., Zaccaro, S. J., Threlfall, K. V., Marks, M. A., \& Mumford, M. D. 2000. Exploring the relationship of leadership skills and knowledge to leader performance. Leadership Quarterly, 11: 65-86.

Cowen, A. P., \& Montgomery, N. V. 2020. To be or not to be sorry? How CEO gender impacts the effectiveness of organizational apologies. Journal of Applied Psychology, 105: 196-208. 
Cragun, O. M., Kari, J. O., \& Wright, P. M. in press. Making CEO narcissism research great: A review and metaanalysis of CEO narcissism. Journal of Management. https://doi.org/10.1177/0149206319892678

Crayne, M. P., \& Hunter, S. T. 2018. Historiometry in organizational science: Renewed attention for an established research method. Organizational Research Methods, 21: 6-29.

Crossland, C., \& Chen, G. 2013. Executive accountability around the world: Sources of cross-national variation in firm performance-CEO dismissal sensitivity. Strategic Organization, 11: 78-109.

Crossland, C., \& Hambrick, D. C. 2011. Differences in managerial discretion across countries: How nation-level institutions affect the degree to which CEOs matter. Strategic Management Journal, 32: 797-819.

Crossland, C., Zyung, J., Hiller, N. J., \& Hambrick, D. C. 2014. CEO career variety: Effects on firm-level strategic and social novelty. Academy of Management Journal, 57: 652-674.

Dalton, D., \& Ortegren, M. 2011. Gender differences in ethics research: The importance of controlling for the social desirability response bias. Journal of Business Ethics, 103: 73-93.

Davis, G. F. 2015. Editorial essay: What is organizational research for? Administrative Science Quarterly, 60: 179- 188.

Dinh, J. E., Lord, R. G., Gardner, W. L., Meuser, J. D., Liden, R. C., \& Hu, J. 2014. Leadership theory and research in the new millennium: Current theoretical trends and changing perspectives. Leadership Quarterly, 25: 36-62.

Dolan, G. 2019, April 10. The rise of CEO activism. CEO Magazine. https:// www.theceomagazine.com/business/management-leadership/ the-rise-of-ceo-activism/

DuBois, S. 2012, February 15. The case for the outspoken CEO, Fortune. https:// fortune.com/2012/02/15/the-case-for-the-outspoken-ceo/

Donaldson, S. I., \& Grant-Vallone, E. J. In Press. Understanding self-report bias in organizational behavior research. Journal of Business and Psychology.

Dwivedi, P., Joshi, A., \& Misangyi, V. F. 2018. Gender-inclusive gatekeeping: How (mostly male) predecessors influence the success of female CEOs. Academy of Management Journal, 61: 379-404.

Ellis, A. P. J. 2006. System breakdown: The role of mental models and transactive memory in the relationship between acute stress and team performance. Academy of Management Journal, 49: 576-589.

Epitropaki, O., Kark, R., Mainemelis, C., \& Lord, R. G. 2017. Leadership and followership identity processes: A multilevel review. Leadership Quarterly, 28: 104-129.

Felin, T., Foss, N. J., \& Ployhart, R. E. 2015. The microfoundations movement in strategy and organization theory. Academy of Management Annals, 9: 575-632.

Ferguson, A. J., Cohen, L. E., Burton, M. D., \& Beckman, C. M. 2015. Misfit and milestones: Structural elaboration and capability reinforcement in the evolution of entrepreneurial top management teams. Academy of Management Journal, 59: 1430-1450. 
Finkelstein, S. 1992. Power in top management teams: Dimensions, measurement, and validation. Academy of Management Journal, 35: 505-538.

Finkelstein, S., Hambrick, D. C., \& Cannella, A. A. 2009. Strategic leadership: Theory and research on executives, top management teams, and boards. Oxford: Oxford University Press.

Friedman, Y., Carmeli, A., \& Tishler, A. 2016. How CEOs and TMTs build adaptive capacity in small entrepreneurial firms. Journal of Management Studies, 53: 996-1018.

Gamache, D. L., \& McNamara, G. 2019. Responding to bad press: How CEO temporal focus influences the sensitivity to negative media coverage of acquisitions. Academy of Management Journal, 62: 918-943.

Gamache, D. L., McNamara, G., Graffin, S. D., Kiley, J. T., Haleblian, J., \& Devers, C. E. 2019. Impression offsetting as an early warning signal of low CEO confidence in acquisitions. Academy of Management Journal, 62: 1-26.

Gamache, D. L., McNamara, G., Mannor, M. J., \& Johnson, R. E. 2015. Motivated to acquire? The impact of CEO regulatory focus on firm acquisitions. Academy of Management Journal, 58: 1261-1282.

Ganster, D. C., Crain, T. L., \& Brossoit, R. M. 2018. Physiological measurement in the organizational sciences: A review and recommendations for future use. Annual Review of Organizational Psychology and Organizational Behavior, 5: 267-293

Georgakakis, D., Greve, P., \& Ruigrok, W. 2017. Top management team fault lines and firm performance: Examining the CEO-TMT interface. Leadership Quarterly, 28: 741-758.

Georgakakis, D., Heyden, M. L., Oehmichen, J. D., \& Ekanayake, U. I. in press. Four decades of CEO-TMT interface research: A review inspired by role theory. Leadership Quarterly. https://doi.org/10.1016/j. leaqua.2019.101354

Goldstein, M. 2017, December 20. Biggest travel story of 2017: The bumping and beating of Dr. David Dao. Forbes. https:// www.forbes.com/sites/michaelgoldstein/2017/12/20/ biggest-travel-story-of-2017-the-bumping-and-beating-of-doctor-david-dao/

Goldvarg, E., \& Johnson-Laird, P. N. 2001. Naive causality: A mental model theory of causal meaning and reasoning. Cognitive Science, 25: 565-610.

Gomulya, D., Wong, E. M., Ormiston, M. E., \& Boeker, W. 2017. The role of facial appearance on CEO selection after firm misconduct. Journal of Applied Psychology, 102: 617-635.

Graffin, S. D., Carpenter, M. A., \& Boivie, S. 2011. What's all that (strategic) noise? Anticipatory impression management in CEO succession. Strategic Management Journal, 32: 748-770.

Graffin, S. D., Hubbard, T. D., Christensen, D. M., \& Lee, E. Y. in press. The influence of CEO risk tolerance on initial pay packages. Strategic Management Journal. https://doi.org/10.1002/smj.3112

Gupta, A., Briscoe, F., \& Hambrick, D. C. 2017. Red, blue, and purple firms: Organizational political ideology and corporate social responsibility. Strategic Management Journal, 38: 1018-1040. 
Gupta, A., \& Wowak, A. J. 2017. The elephant (or donkey) in the boardroom: How board political ideology affects CEO pay. Administrative Science Quarterly, 62: 1-30.

Gupta, V. K., Han, S., Mortal, S. C., Silveri, S. D., \& Turban, D. B. 2018. Do women CEOs face greater threat of shareholder activism compared to male CEOs? A role congruity perspective. Journal of Applied Psychology, 103: 228-236.

Hafenbradl, S., \& Waeger, D. 2016. Ideology and the micro-foundations of CSR: Why executives believe in the business case for CSR and how this affects their CSR engagements. Academy of Management Journal, 60: 1582-1606.

Hahn, T., Preuss, L., Pinkse, J., \& Figge, F. 2014. Cognitive frames in corporate sustainability: Managerial sensemaking with paradoxical and business case frames. Academy of Management Review, 39: 463-487.

Hambrick, D. C. 1995. Fragmentation and the other problems CEOs have with their top management teams. California Management Review, 37: 110-127.

Hambrick, D. C. 2005. Upper echelons theory: Origins, twists and turns, and lessons learned. In K.G. Smith and M.A. Hitt (Eds.), Great minds in management: The process of theory development: 109-127. New York: Oxford University Press.

Hambrick, D. C. 2007. Upper echelons theory: An update. Academy of Management Review, 32: 334-343.

Hambrick, D. C. 2019. Keynote address presented at the Strategic Management Society Special Conference, Las Vegas, NV.

Hambrick, D. C., \& Finkelstein, S. 1987. Managerial discretion: A bridge between polar views of organizational outcomes. Research in Organizational Behavior, 9: 369-406.

Hambrick, D. C., Finkelstein, S., \& Mooney, A. C. 2005. Executive job demands: New insights for explaining strategic decisions and leader behaviors. Academy of Management Review, 30: 472-491.

Hambrick, D. C., \& Lovelace, J. B. 2018. The role of executive symbolism in advancing new strategic themes in organizations: A social influence perspective. Academy of Management Review, 43: 110-131.

Hambrick, D. C., \& Mason, P. A. 1984. Upper echelons: The organization as a reflection of its top managers. Academy of Management Review, 9: 193-206.

Hambrick, D. C., \& Quigley, T. J. 2014. Toward more accurate contextualization of the CEO effect on firm performance. Strategic Management Journal, 35: 473-491.

Hambrick, D. C., \& Wowak, A. in press. CEO sociopolitical activism: A stakeholder alignment model. Academy of Management Review. https://doi.org/10.5465/ amr.2018.0084

Hamilton, B. H., \& Nickerson, J. A. 2003. Correcting for endogeneity in strategic management research. Strategic Organization, 1: 51-78.

Han, Q., Jennings, J. E., Liu, R., \& Jennings, P. D. 2019. Going home and helping out? Returnees as propagators of CSR in an emerging economy. Journal of International Business Studies, 50: 857-872.

Harrison, J. S., Thurgood, G. R., Boivie, S., \& Pfarrer, M. D. 2019. Measuring CEO personality: Developing, validating, and testing a linguistic tool. Strategic Management Journal, 40: 1316-1330. 
Hartnell, C. A., Kinicki, A. J., Lambert, L. S., Fugate, M., \& Doyle Corner, P. 2016. Do similarities or differences between CEO leadership and organizational culture have a more positive effect on firm performance? A test of competing predictions. Journal of Applied Psychology, 101: 846-861.

Hasan, S., \& Koning, R. 2019. Prior ties and the limits of peer effects on startup team performance. Strategic Management Journal, 40: 1394-1416.

Healey, M. P., \& Hodgkinson, G. P. 2014. Rethinking the philosophical and theoretical foundations of organizational neuroscience: A critical realist alternative. Human Relations, 67: 765-792.

Heavey, C., \& Simsek, Z. 2015. Transactive memory systems and firm performance: An upper echelons perspective. Organization Science, 26: 941-959.

Heavey, C., \& Simsek, Z. 2017. Distributed cognition in top management teams and organizational ambidexterity: The influence of transactive memory systems. Journal of Management, 43: 919-945.

Heavey, C., Simsek, Z., Roche, F., \& Kelly, A. 2009. Decision comprehensiveness and corporate entrepreneurship: The moderating role of managerial uncertainty preferences and environmental dynamism. Journal of Management Studies, 46: 1289-1314.

Hedlund, J., Forsythe, G. B., Horvath, J. A., Williams, W. M., Snook, S., \& Sternberg, R. J. 2003. Identifying and assessing tacit knowledge: Understanding the practical intelligence of military leaders. Leadership Quarterly, 14: 117-140.

Helfat, C. E., \& Martin, J. A. 2015. Dynamic managerial capabilities. Journal of Management, 41: 1281-1312.

Helfat, C. E., \& Peteraf, M. A. 2015. Managerial cognitive capabilities and the microfoundations of dynamic capabilities. Strategic Management Journal, 36: 831-850.

Herrmann, P., \& Nadkarni, S. 2014. Managing strategic change: The duality of CEO personality. Strategic Management Journal, 35: 1318-1342.

Heyden, M. L. M., van Doorn, S., Reimer, M., Van Den Bosch, F. A. J., \& Volberda, H. W. 2013. Perceived environmental dynamism, relative competitive performance, and top management team heterogeneity: Examining correlates of upper echelons' advice-seeking. Organization Studies, 34: 1327-1356.

Hill, A. D., Recendes, T., \& Ridge, J. W. 2019. Second-order effects of CEO characteristics: How rivals' perceptions of CEOs as submissive and provocative precipitate competitive attacks. Strategic Management Journal, 40: 809-835.

Hill, A. D., White, M. A., \& Wallace, J. C. 2014. Unobtrusive measurement of psychological constructs in organizational research. Organizational Psychology Review, 4: 148-174.

Hiller, N. J., DeChurch, L. A., Murase, T., \& Doty, D. 2011. Searching for outcomes of leadership: A 25-year review. Journal of Management, 37: 1137-1177.

Hodgkinson, G. P., \& Sparrow, P. R. 2002. The competent organization: A psychological analysis of the strategic management process. Maidenhead, UK: Open University Press.

Hoobler, J. M., Masterson, C. R., Nkomo, S. M., \& Michel, E. J. 2018. The business case for women leaders: Metaanalysis, research critique, and path forward. Journal of Management, 44: 2473-2499. 
Hoskisson, R. E., Chirico, F., Zyung, J., \& Gambeta, E. 2017. Managerial risk taking: A multitheoretical review and future research agenda. Journal of Management, 43: 137-169.

Hutzschenreuter, T., \& Horstkotte, J. 2013. Performance effects of top management team demographic faultlines in the process of product diversification. Strategic Management Journal, 34: 704-726.

Hutzschenreuter, T., Kleindienst, I., \& Greger, C. 2012. How new leaders affect strategic change following a succession event: A critical review of the literature. Leadership Quarterly, 23: 729-755.

Jack, A. I., Rochford, K. C., Friedman, J. P., Passarelli, A. M., \& Boyatzis, R. E. 2019. Pitfalls in organizational neuroscience: A critical review and suggestions for future research. Organizational Research Methods, 22: 421-458.

Jacquart, P., \& Antonakis, J. 2014. When does charisma matter for top-level leaders? Effect of attributional ambiguity. Academy of Management Journal, 58: 1051-1074.

Jensen, M., \& Zajac, E. J. 2004. Corporate elites and corporate strategy: How demographic preferences and structural position shape the scope of the firm. Strategic Management Journal, 25: 507-524.

Jeong, S.-H., \& Harrison, D. A. 2017. Glass breaking, strategy making, and value creating: Meta-analytic outcomes of women as CEOs and TMT members. Academy of Management Journal, 60: 1219-1252.

Judge, T. A. 2019. Problems or mysteries: The state of leadership research and practice. Paper presented at the Annual New Directions in Leadership Research Conference, Durham, NC.

Jung, H., Vissa, B., \& Pich, M. 2017. How do entrepreneurial founding teams allocate task positions? Academy of Management Journal, 60: 264-294.

Jung, J., \& Shin, T. 2018. Learning not to diversify: The transformation of graduate business education and the decline of diversifying acquisitions. Administrative Science Quarterly, 4: 337-369.

Kim, E.-H., \& Youm, Y. N. 2017. How do social media affect analyst stock recommendations? Evidence from S\&P 500 electric power companies' twitter accounts Strategic Management Journal, 38: 2599-2622.

Kish-Gephart, J. J., \& Campbell, J. T. 2015. You don't forget your roots: The influence of CEO social class background on strategic risk taking. Academy of Management Journal, 58: 1614-1636.

Klein, F. B., Chaigneau, P., \& Devers, C. E. in press. CEO gender-based termination concerns: Evidence from initial severance agreements. Journal of Management. https://doi.org/10.1177/0149206319887421

Klotz, A. C., Hmieleski, K. M., Bradley, B. H., \& Busenitz, L. W. 2014. New venture teams: A review of the literature and roadmap for future research. Journal of Management, 40: 226-255.

Kohler, T., \& Cortina, J. M. in press. Play it again, Sam! An analysis of constructive replication in the organizational sciences. Journal of Management. https://doi. org/10.1177/0149206319843985

Konig, A. S., Graf-Vlachy, L., Bundy, J. N., \& Little, L. 2020. A blessing and a curse: How CEOs' empathy affects their management of organizational crises. Academy of Management Review, 45: 130-153. 
Krause, R., Whitler, K. A., \& Semadeni, M. 2014. Power to the principals! An experimental look at shareholder say-on-pay voting. Academy of Management Journal, 57: 94-115.

Lawrence, B. S. 1997. Perspective: The black box of organizational demography. Organization Science, 8: 1-22.

Li, Q., Maggitti, P. G., Smith, K. G., Tesluk, P. E., \& Katila, R. 2013. Top management attention to innovation: The role of search selection and intensity in new product introductions. Academy of Management Journal, 56: 893-916.

Li, J., \& Tang, Y. 2010. CEO hubris and firm risk taking in china: The moderating role of managerial discretion. Academy of Management Journal, 53: 45-68.

Ling, Y., Wei, L., Klimoski, R. J., \& Wu, L. 2015. Benefiting from CEO's empowerment of TMTs: Does CEO- TMT dissimilarity matter? Leadership Quarterly, 26: 1066-1079.

Liu, D., Fisher, G., \& Chen, G. 2018. CE0 attributes and firm performance: A sequential mediation process model. Academy of Management Annals, 12: 789-816.

Lorsch, J. W. 2017. Understanding boards of directors: A systems perspective. Annals of Corporate Governance, 2: 1-49.

Loued-Khenissi, L., Doll, O., \& Preuschoff, K. 2019. An overview of functional magnetic resonance imaging techniques for organizational research. Organizational Research Methods, 22: 17-45.

Love, E. G., Lim, J., \& Bednar, M. K. 2017. The face of the firm: The influence of CEOs on corporate reputation. Academy of Management Journal, 60: 1462-1481.

Lovelace, J. B., Bundy, J., Hambrick, D. C., \& Pollock, T. G. 2018. The shackles of CEO celebrity: Sociocognitive and behavioral role constraints on "star" leaders. Academy of Management Review, 43: 419-444.

Maak, T., Pless, N. M., \& Voegtlin, C. 2016. Business statesman or shareholder advocate? CEO responsible leadership styles and the micro-foundations of political CSR. Journal of Management Studies, 53: 463-493.

Maitlis, S., \& Christianson, M. 2014. Sensemaking in organizations: Taking stock and moving forward. Academy of Management Annals, 8: 57-125.

Malhotra, S., Morgan, H. M., \& Zhu, P. 2018. Sticky decisions: Anchoring and equity stakes in international acquisitions. Journal of Management, 44: 3200-3230.

Mannor, M. J., Matta, F. K., Block, E. S., Steinbach, A. L., \& Davis, J. H. 2019. A liability of breadth? The conflicting influences of experiential breadth on perceptions of founding teams. Journal of Management, 45: 1540-1568.

Mannor, M. J., Wowak, A. J., Bartkus, V. O., \& Gomez-Mejia, L. R. 2016. Heavy lies the crown? How job anxiety affects top executive decision making in gain and loss contexts. Strategic Management Journal, 37: 1968-1989.

Mackey, A. 2008. The effect of CEOs on firm performance. Strategic Management Journal, 29: 1357-1367.

Markoczy, L. 1997. Measuring beliefs: Accept no substitutes. Academy of Management Journal, 40: 1228-1242.

Mayer, D. 2017. The law and ethics of CEO social activism. Journal of Law, Business \& Ethics, 23: 21-44. 
Menz, M. 2012. Functional top management team members: A review, synthesis, and research agenda. Journal of Management, 38: 45-80.

Mintzberg, H. 1973. The nature of managerial work. New York: Harper \& Row.

Mohr, A., \& Batsakis, G. 2018. The contingent effect of TMT international experience on firms' internationalization speed. British Journal of Management, 30: 869-887.

Moorman, R. H., \& Podsakoff, P. M. 1992. A meta-analytic review and empirical test of the potential confounding effects of social desirability response sets in organizational behaviour research. Journal of Occupational and Organizational Psychology, 65: 131-149.

Mumford, M. D. 2006. Pathways to outstanding leadership: A comparative analysis of charismatic, ideological, and pragmatic leaders. Mahwah, NJ: Lawrence Erlbaum.

Mumford, M. D., Todd, E. M., Higgs, C., \& McIntosh, T. 2017. Cognitive skills and leadership performance: The nine critical skills. Leadership Quarterly, 28: 24-39.

Ndofor, H. A., Sirmon, D. G., \& He, X. 2015. Utilizing the firm's resources: How TMT heterogeneity and resulting faultlines affect TMT tasks. Strategic Management Journal, 36: 1656-1674.

Nielsen, B. B., \& Nielsen, S. 2013. Top management team nationality diversity and firm performance: A multilevel study. Strategic Management Journal, 34: 373-382.

Oh, I.-S., Wang, G., \& Mount, M. K. 2011. Validity of observer ratings of the five-factor model of personality traits: A meta-analysis. Journal of Applied Psychology, 96: 762-773.

Oreg, S., \& Berson, Y. 2018. Leaders' impact on organizational change: Bridging theoretical and methodological chasms. Academy of Management Annals, 13: 272-307.

Ortiz-de-Mandojana, N., Bansal, P., \& Aragon-Correa, J. A. 2019. Older and wiser: How CEOs' time perspective influences long-term investments in environmentally responsible technologies. British Journal of Management, 30: 134-150.

Ou, A. Y., Seo, J., Choi, D., \& Hom, P. W. 2016. When can humble top executives retain middle managers? The moderating role of top management team faultlines. Academy of Management Journal, 60: 1915-1931.

Ou, A. Y., Tsui, A. S., Kinicki, A. J., Waldman, D. A., Xiao, Z., \& Song, L. J. 2014. Humble chief executive officers' connections to top management team integration and middle managers' responses. Administrative Science Quarterly, 59: 34-72.

Park, G., Schwartz, H. A., Eichstaedt, J. C., Kern, M. L., Kosinski, M., Stillwell, D. J., . . Seligman, M. E. P. 2015. Automatic personality assessment through social media language. Journal of Personality and Social Psychology, 108: 934.

Parkinson, C., Kleinbaum, A. M., \& Wheatley, T. 2017. Spontaneous neural encoding of social network position. Nature Human Behaviour, 1: 0072.

Parmigiani, A., \& King, E. 2019. Successfully proposing and composing review papers. Journal of Management, 45: 3083-3090.

Pashler, H., \& Wagenmakers, E. 2012. Editors' introduction to the special section on replicability in psychological science: A crisis of confidence? Perspectives on Psychological Science, 7: 528-530.

Peterson, S. J., Galvin, B. M., \& Lange, D. 2012. CEO servant leadership: Exploring executive characteristics and firm performance. Personnel Psychology, 65: 565-596. 
Petrenko, O. V., Aime, F., Ridge, J., \& Hill, A. 2016. Corporate social responsibility or CEO narcissism? CSR motivations and organizational performance. Strategic Management Journal, 37: 262-279.

Petrenko, O. V., Aime, F., Recendes, T., \& Chandler, J. A. 2019. The case for humble expectations: CEO humility and market performance. Strategic Management Journal, 40: 1938-1964.

Pettigrew, A. M. 1992. On studying managerial elites. Strategic Management Journal, 13: $163-182$.

Pfarrer, M. D., Devers, C. E., Corley, K., Cornelissen, J. P., Lange, D., Makadok, R., Mayer, K., \& Weber, L. 2019. Sociocognitive perspectives in strategic management. Academy of Management Review, 44: 767-774.

Pratt, M. G. 2009. From the editors: For the lack of a boilerplate: Tips on writing up (and reviewing) qualitative research. Academy of Management Journal, 52: 856-862.

Price, R. 2018, 19 June. Read the memo Uber sent its employees about using its legal team to help separated families on the Mexico border. https://www. businessinsider.com/uber-ceo-trump-family-separation-policy-2018-6

Priem, R. L., Lyon, D. W., \& Dess, G. G. 1999. Inherent limitations of demographic proxies in top management team heterogeneity research. Journal of Management, 25: 935-953.

Pryor, C., Holmes, R. M., Webb, J. W., \& Liguori, E. W. 2019. Top executive goal orientations' effects on environmental scanning and performance: Differences between founders and nonfounders. Journal of Management, 45: 1958-1986.

Qian, C., Cao, Q., \& Takeuchi, R. 2013. Top management team functional diversity and organizational innovation in China: The moderating effects of environment. Strategic Management Journal, 34: 110-120.

Quigley, T. J., Crossland, C., \& Campbell, R. J. 2017. Shareholder perceptions of the changing impact of CEOs: Market reactions to unexpected CEO deaths, 19502009. Strategic Management Journal, 38: 939-949.

Quigley, T. J., \& Graffin, S. D. 2017. Reaffirming the CEO effect is significant and much larger than chance: A comment on Fitza (2014). Strategic Management Journal, 38: 793-801.

Quigley, T. J., \& Hambrick, D. C. 2012. When the former CEO stays on as board chair: Effects on successor discretion, strategic change, and performance. Strategic Management Journal, 33: 834-859.

Quigley, T. J., \& Hambrick, D. C. 2015. Has the "CEO effect" increased in recent decades? A new explanation for the great rise in America's attention to corporate leaders. Strategic Management Journal, 36: 821-830.

Quigley, T. J., Hubbard, T. D., Ward, A., \& Graffin, S. D. 2020. Unintended consequences: Information releases and CEO stock option grants. Academy of Management Journal, 63: 155-180.

Raes, A. M. L., Heijltjes, M. G., Glunk, U., \& Roe, R. A. 2011. The interface of the top management team and middle managers: A process model. Academy of Management Review, 36: 102-126. 
Reklaitis, V. 2017, April 11. United's stock falls 1.1\%, wipes out $\$ 255$ million off the airline's market cap. MarketWatch. https://www.marketwatch.com/ story/uniteds-stock-is-set-to-fall-5-and-wipe-1-billion-off-theairlines-marketcap-2017-04-11

Resick, C. J., Whitman, D. S., Weingarden, S. M., \& Hiller, N. J. 2009. The bright-side and the dark-side of CEO personality: Examining core self-evaluations, narcissism, transformational leadership, and strategic influence. Journal of Applied Psychology, 94: 1365-1381.

Richard, O. C., Wu, J., Markoczy, L. A., \& Chung, Y. 2019. Top management team demographic-faultline strength and strategic change: What role does environmental dynamism play? Strategic Management Journal, 40: 987- 1009.

Rowe, A. L., \& Cooke, N. J. 1995. Measuring mental models: Choosing the right tools for the job. Human Resource Development Quarterly, 6: 243-255.

Rubin, D. B. 2008. For objective causal inference, design trumps analysis. Annals of Applied Statistics, 2: 808-840.

Rynes, S. L., Colbert, A. E., \& O'Boyle, E. H. 2018. When the "best available evidence" doesn't win: How doubts about science and scientists threaten the future of evidence-based management. Journal of Management, 44: 2995-3010.

Samba, C., Williams, D. W., \& Fuller, R. M. in press. The forms and use of intuition in top management teams. Leadership Quarterly. https://doi.org/10.1016/j. leaqua.2019.101349

Sauerwald, S., Lin, Z. J., \& Peng, M. W. 2016. Board social capital and excess CEO returns: Board social capital and excess CEO returns. Strategic Management Journal, 37: 498-520.

Schubert, T., \& Tavassoli, S. 2020. Product innovation and educational diversity in top and middle management teams. Academy of Management Journal, 63: 272-294.

Schwab, A., \& Starbuck, W. H. 2017. A call for openness in research reporting: How to turn covert practices into helpful tools. Academy of Management Learning \& Education, 16: 125-141.

Semadeni, M., Withers, M. C., \& Certo, S. T. 2014. The perils of endogeneity and instrumental variables in strategy research: Understanding through simulations. Strategic Management Journal, 35: 1070-1079.

Short, J. 2009. The art of writing a review article. Journal of Management, 35: 1312-1317.

Simsek, Z., Heavey, C., \& Fox, B. C. 2018. Interfaces of strategic leaders: A conceptual framework, review, and research agenda. Journal of Management, 44: 280-324.

Smith, A. N., Watkins, M. B., Ladge, J. J., \& Carlton, P. 2019. Making the invisible visible: Paradoxical effects of intersectional invisibility on the career experiences of executive Black women. Academy of Management Journal, 62: 1705-1734.

Smith, M. B., Hill, A. D., Wallace, J. C., Recendes, T., \& Judge, T. A. 2018. Upsides to dark and downsides to bright personality: A multidomain review and future research agenda. Journal of Management, 44: 191-217.

Smith, W. K. 2014. Dynamic decision making: A model of senior leaders managing strategic paradoxes. Academy of Management Journal, 57: 1592-1623. 
Sonpar, K., \& Golden-Biddle, K. 2008. Using content analysis to elaborate adolescent theories of organization. Organizational Research Methods, 11: 795-814.

Souitaris, V., Zerbinati, S., Peng, B. G., \& Shepherd, D. A. 2020. Should I stay or should I go? Founder power and exit via initial public offering. Academy of Management Journal, 63: 64-95.

Steinbach, A., Gamache, D. L., \& Johnson, R. E. 2019. Don't get it misconstrued: Construal level shifts and flexibility in the upper echelons. Academy of Management Review, 44: 871-895.

Stern, I., \& Westphal, J. D. 2010. Stealthy footsteps to the boardroom: Executives' backgrounds, sophisticated interpersonal influence behavior, and board appointments. Administrative Science Quarterly, 55: 278-319.

Stillman, J. 2018, June 20. Uber's CEO, once a refugee himself, is taking extraordinary action to help families separated at the border. Inc. https://www.inc.com/jessicastillman/ubers-ceo-just-took-extraordinary-action-tohelp-migrants-separatedfrom-their-children.html

Stoker, J. I., Grutterink, H., \& Kolk, N. J. 2012. Do transformational CEOs always make the difference? The role of TMT feedback seeking behavior. Leadership Quarterly, 23: 582-592.

Tivadar, R. I., \& Murray, M. M. 2019. A primer on electroencephalography and eventrelated potentials for organizational neuroscience. Organizational Research Methods, 22: 69-94.

Tuggle, C. S., Schnatterly, K., \& Johnson, R. A. 2010. Attention patterns in the boardroom: How board composition and processes affect discussion of entrepreneurial issues. Academy of Management Journal, 53: 550-571.

Tunarosa, A., \& Glynn, M. A. 2017. Strategies of integration in mixed methods research: Insights using relational algorithms. Organizational Research Methods, 20: 224-242.

Uhl-Bien, M., Riggio, R. E., Lowe, K. B., \& Carsten, M. K. 2014. Followership theory: A review and research agenda. Leadership Quarterly, 25: 83-104.

Waldman, D. A., Wang, D., \& Fenters, V. 2019. The added value of neuroscience methods in organizational research. Organizational Research Methods, 22: 223-249.

Wang, G., Holmes Jr., R. M., Oh, I.-S., \& Zhu, W. 2016. Do CEOs matter to firm strategic actions and firm performance? A meta-analytic investigation based on upper echelons theory. Personnel Psychology, 69: 775-862.

Wang, H., Tsui, A. S., \& Xin, K. R. 2011. CEO leadership behaviors, organizational performance, and employees' attitudes. Leadership Quarterly, 22: 92-105.

Wangrow, D. B., Schepker, D. J., \& Barker, V. L. 2015. Managerial discretion: An empirical review and focus on future research directions. Journal of Management, 41: 99-135.

Weick, K. E. 1995. Sensemaking in organizations. Thousand Oaks, CA: Sage.

Weick, K. E., Sutcliffe, K. M., \& Obstfeld, D. 2005. Organizing and the process of sensemaking. Organization Science, 16: 409-421.

Westphal, J. D., Park, S. H., McDonald, M. L., \& Hayward, M. L. A. 2012. Helping other CEOs avoid bad press: Social exchange and impression management 
support among CEOs in communications with journalists. Administrative Science Quarterly, 57: 217-268.

Westphal, J. D., \& Shani, G. 2016. Psyched-up to suck-up: Self-regulated cognition, interpersonal influence, and recommendations for board appointments in the corporate elite. Academy of Management Journal, 59: 479-509.

Wigboldus, D. H., \& Dotsch, R. 2016. Encourage playing with data and discourage questionable reporting practices. Psychometrika, 81: 27-32.

Woehr, D. J., Loignon, A. C., Schmidt, P. B., Loughry, M. L., \& Ohland, M. W. 2015. Justifying aggregation with consensus-based constructs: A review and examination of cutoff values for common aggregation indices. Organizational Research Methods, 18: 704-737.

Wolfolds, S. E., \& Siegel, J. 2019. Misaccounting for endogeneity: The peril of relying on the Heckman two-step method without a valid instrument. Strategic Management Journal, 40: 432-462.

Wong, E. M., Ormiston, M. E., \& Tetlock, P. E. 2011. The effects of top management team integrative complexity and decentralized decision making on corporate social performance. Academy of Management Journal, 54: 1207-1228.

Wowak, A. J., Gomez-Mejia, L. R., \& Steinbach, A. L. 2017. Inducements and motives at the top: A holistic perspective on the drivers of executive behavior. Academy of Management Annals, 11: 669-702.

Wowak, A. J., Mannor, M. J., Arrfelt, M., \& McNamara, G. 2016. Earthquake or glacier? How CEO charisma manifests in firm strategy over time. Strategic Management Journal, 37: 586-603.

Wright, C., \& Nyberg, D. 2017. An inconvenient truth: How organizations translate climate change into business as usual. Academy of Management Journal, 60: 1633-1661.

Yi, X., Zhang, Y. A., \& Windsor, D. in press. You are great and I am great (too): Examining new CEOs' social influence behaviors during leadership transition. Academy of Management Journal. https://doi.org/10.5465/amj.2018.0365

Zhang, H., Ou, A. Y., Tsui, A. S., \& Wang, H. 2017. CEO humility, narcissism and firm innovation: A paradox perspective on CEO traits. Leadership Quarterly, 28: 585-604.

Zhang, X., Li, N., Ullrich, J., \& van Dick, R. 2015. Getting everyone on board: The effect of differentiated transformational leadership by CEOs on top management team effectiveness and leader-rated firm performance. Journal of Management, 41: 1898-1933.

Zhang, Y., \& Qu, H. 2015. The impact of CEO succession with gender change on firm performance and successor early departure: Evidence from China's publicly listed companies in 1997-2010. Academy of Management Journal, 59: 1845-1868.

Zhu, D. H., \& Shen, W. 2016. Why do some outside successions fare better than others? The role of outside CEOs' prior experience with board diversity. Strategic Management Journal, 37: 2695-2708. 


\section{SUPPLEMENTAL APPENDIX}

Article Sample List Identification

We identified our sample of UET research articles by building on the process used in the impactful review on TMTs in UET by Carpenter and colleagues (2004). To increase the inclusiveness of our search, we added several additional journals that publish high quality empirical and conceptual research on UET. We searched for work published since 2009 in the following outlets: Academy of Management Journal, Academy of Management Review, Administrative Science Quarterly, British Journal of Management, Human Relations, Journal of Applied Psychology, Journal of Business and Psychology, Journal of International Business Studies, Journal of Management, Journal of Management Studies, Leadership Quarterly, Management Science, Organization Science, Organization Studies, Personnel Psychology, and Strategic Management Journal. Articles were identified by searching articles published in these journals for the terms "CEO", "executive", "TMT", or "Top Management Team" in the abstracts of journal articles and the terms "UET" or "Upper Echelon" or "Upper Echelons" anywhere in the article text (including the references). We then reviewed the results produced by this search and excluded any articles that did not utilize the UET perspective (e.g., only had the term "upper echelons" in a reference list but did not significantly address relevant concepts). The final set of 217 articles is listed below. 
Full List of Articles Reviewed (From 2009-Present)

Acharya, A. G., \& Pollock, T. G. 2013. Shoot for the stars? Predicting the recruitment of prestigious directors at newly public firms. Academy of Management Journal, 56: 1396-1419.

Adams, M., \& Jiang, W. 2017. Do chief executives' traits affect the financial performance of risktrading firms? Evidence from the UK insurance industry. British Journal of Management, 28: 481-501.

Aguinis, H., \& Solarino, A. M. in press. Transparency and replicability in qualitative research: The case of interviews with elite informants. Strategic Management Journal.

Ateş, N. Y., Tarakci, M., Porck, J. P., van Knippenberg, D., \& Groenen, P. J. F. in press. The dark side of visionary leadership in strategy implementation: Strategic alignment, strategic consensus, and commitment. Journal of Management.

Alexiev, A. S., Jansen, J. J. P., Van den Bosch, F. A. J., \& Volberda, H. W. 2010. Top management team advice seeking and exploratory innovation: the moderating role of TMT heterogeneity. Journal of Management Studies, 47: 1343-1364.

Banalieva, E. R., \& Eddleston, K. A. 2011. Home-region focus and performance of family firms: The role of family vs non-family leaders. Journal of International Business Studies, 42: 1060-1072.

Bao, S., Fainshmidt, S., Nair, A., \& Vracheva, V. 2014. Women in upper echelons of management, tenure and legal risk. British Journal of Management, 25: 388-405.

Barrick, M. R., Thurgood, G. R., Smith, T. A., \& Courtright, S. H. 2015. Collective organizational engagement: linking motivational antecedents, strategic implementation, and firm performance. Academy of Management Journal, 58: 111-135.

Belenzon, S., Shamshur, A., \& Zarutskie, R. 2019. CEO’s age and the performance of closely held firms. Strategic Management Journal, 40: 917-944. 
Benischke, M. H., Martin, G. P., \& Glaser, L. 2019. CEO equity risk bearing and strategic risk taking: The moderating effect of CEO personality. Strategic Management Journal, 40: 153-177.

Bentley, F. S., Fulmer, I. S., \& Kehoe, R. R. 2019. Payoffs for layoffs? An examination of CEO relative pay and firm performance surrounding layoff announcements. Personnel Psychology, 72: 81-106.

Bergh, D. D., Aguinis, H., Heavey, C., Ketchen, D. J., Boyd, B. K., Su, P., Lau, C. L. L., \& Joo, H. 2016. Using meta-analytic structural equation modeling to advance strategic management research: Guidelines and an empirical illustration via the strategic leadership-performance relationship. Strategic Management Journal, 37: 477-497.

Bermiss, Y. S., \& Murmann, J. P. 2015. Who matters more? The impact of functional background and top executive mobility on firm survival. Strategic Management Journal, 36: 1697-1716.

Bilgili, H., Campbell, J., O’Leary-Kelly, A. M., Ellstrand, A. E., \& Johnson, J. L. in press. The final countdown: Regulatory focus and the phases of CEO retirement. Academy of Management Review.

Bilgili, T. V., Calderon, C. J., Allen, D. G., \& Kedia, B. L. 2017. Gone with the wind: A meta-analytic review of executive turnover, its antecedents, and postacquisition performance. Journal of Management, 43: 1966-1997.

Bilgili, H., Campbell, J., O'Leary-Kelly, A. M., Ellstrand, A. E., \& Johnson, J. L. in press. The final countdown: Regulatory Focus and the Phases of CEO Retirement. Academy of Management Review.

Blagoeva, R., Mom, T. J., Jansen, J. J., \& George, G. in press. Problem-solving or self-enhancement? a power perspective on how CEOs affect R\&D search in the face of inconsistent feedback. Academy of Management Journal. 
Boehm, S. A., Dwertmann, D. J. G., Bruch, H., \& Shamir, B. 2015. The missing link? Investigating organizational identity strength and transformational leadership climate as mechanisms that connect CEO charisma with firm performance. The Leadership Quarterly, 26: 156-171.

Boivie, S., Graffin, S. D., \& Pollock, T. G. 2012. Time for me to fly: Predicting director exit at large firms. Academy of Management Journal, 55: 1334-1359.

Boone, C., \& Hendriks, W. 2009. Top management team diversity and firm performance: Moderators of functional-background and locus-of-control diversity. Management Science, 55: $165-180$.

Boone, C., Lokshin, B., Guenter, H., \& Belderbos, R. 2019. Top management team nationality diversity, corporate entrepreneurship, and innovation in multinational firms. Strategic Management Journal, 40: 277-302.

Booth, T., Murray, A. L., Overduin, M., Matthews, M., \& Furnham, A. 2016. Distinguishing CEOs from top level management: A profile analysis of individual differences, career paths and demographics. Journal of Business and Psychology, 31: 205-216.

Boyd, B. K., Haynes, K. T., \& Zona, F. 2011. Dimensions of CEO-board relations. Journal of Management Studies, 48: 1892-1923.

Brands, R. A., \& Fernandez-Mateo, I. 2017. Leaning out: How negative recruitment experiences shape women's decisions to compete for executive roles. Administrative Science Quarterly, 62: 405-442.

Brauer, M., \& Wiersema, M. 2018. Analyzing analyst research: A review of past coverage and recommendations for future research. Journal of Management, 44: 218-248.

Briscoe, F., Chin, M. K., \& Hambrick, D. C. 2014. CEO ideology as an element of the corporate opportunity structure for social activists. Academy of Management Joumal, 57: 1786-1809. 
Buyl, T., Boone, C., \& Hendriks, W. 2014. Top management team members' decision influence and cooperative behaviour: An empirical study in the information technology industry. British Journal of Management, 25: 285-304.

Buyl, T., Boone, C., \& Wade, J. B. 2019. CEO narcissism, risk-taking, and resilience: An empirical analysis in U.S. commercial banks. Journal of Management, 45: 1372-1400.

Buyl, T., Boone, C., Hendriks, W., \& Matthyssens, P. 2011. Top management team functional diversity and firm performance: The moderating role of CEO characteristics. Journal of Management Studies, 48: 151-177.

Campbell, R., Jeong, S.-H., \& Graffin, S. D. in press. Born to take risk? The effect of CEO birth order on strategic risk taking. Academy of Management Journal.

Cao, Q., Simsek, Z., \& Jansen, J. J. P. 2015. CEO social capital and entrepreneurial orientation of the firm: Bonding and bridging effects. Journal of Management, 41: 1957-1981.

Cao, Q., Simsek, Z., \& Zhang, H. 2009. Modelling the joint impact of the CEO and the TMT on organizational ambidexterity. Journal of Management Studies.

Carmeli, A., Schaubroeck, J., \& Tishler, A. 2011. How CEO empowering leadership shapes top management team processes: Implications for firm performance. The Leadership Quarterly, 22: 399-411.

Carton, A. M., \& Lucas, B. J. 2018. How can leaders overcome the blurry vision bias? Identifying an antidote to the paradox of vision communication. Academy of Management Journal, 61: 21062129.

Chan, R. Y. K., Cheng, L. T. W., \& Leung, T. Y. 2011. Corporate performance implications of relational demographic differences: On age and titles of chairpersons versus general managers of listed Chinese companies. British Journal of Management, 22: 96-113. 
Chatterjee, A., \& Pollock, T. G. 2017. Master of puppets: How narcissistic CEOs construct their professional worlds. Academy of Management Review, 42: 703-725.

Chen, G., \& Hambrick, D. C. 2012. CEO replacement in turnaround situations: Executive (mis)fit and its performance implications. Organization Science, 23: 225-243.

Chen, G., Crossland, C., \& Huang, S. in press. That could have been me: Director deaths, CEO mortality salience, and corporate prosocial behavior. Management Science.

Chen, G., Crossland, C., \& Luo, S. 2015. Making the same mistake all over again: CEO overconfidence and corporate resistance to corrective feedback. Strategic Management Journal, 36: 1513-1535.

Chen, G., Treviño, L. K., \& Hambrick, D. C. 2009. CEO elitist association: Toward a new understanding of an executive behavioral pattern. The Leadership Quarterly, 20: 316-328.

Chen, J., \& Nadkarni, S. 2017. It's about time! CEOs' temporal dispositions, temporal leadership, and corporate entrepreneurship. Administrative Science Quarterly, 62: 31-66.

Chen, M.J., Lin, H.C., \& Michel, J. G. 2010. Navigating in a hypercompetitive environment: the roles of action aggressiveness and TMT integration. Strategic Management Journal, 31: 1410_ 1430.

Chin, M. K., \& Semadeni, M. 2017. CEO political ideologies and pay egalitarianism within top management teams. Strategic Management Journal, 38: 1608-1625.

Chin, M. K., Hambrick, D. C., \& Treviño, L. K. 2013. Political ideologies of CEOs: The influence of executives' values on corporate social responsibility. Administrative Science Quarterly, 58: 197232.

Christensen, D. M., Dhaliwal, D. S., Boivie, S., \& Graffin, S. D. 2015. Top management conservatism and corporate risk strategies: Evidence from managers' personal political orientation and corporate tax avoidance. Strategic Management Journal, 36: 1918-1938. 
Clark, J. R., Murphy, C., \& Singer, S. J. 2014. When do leaders matter? Ownership, governance and the influence of CEOs on firm performance. The Leadership Quarterly, 25: 358-372.

Clark, K. D., \& Maggitti, P. G. 2012. TMT potency and strategic decision-making in high technology firms. Journal of Management Studies, 49: 1168-1193.

Colbert, A. E., Barrick, M. R., \& Bradley, B. H. 2014. Personality and leadership composition in top management teams: Implications for organizational effectiveness. Personnel Psychology, 67: $351-387$.

Cooper, D., Patel, P. C., \& Thatcher, S. M. B. 2014. It depends: Environmental context and the effects of faultlines on top management team performance. Organization Science, 25: 633-652.

Cordero, A. M., \& Miller, S. R. in press. Political party tenure and MNE location choices. Journal of International Business Studies.

Corgun, O.M., Kari, J.O., Wright, P.M. in press. Making CEO narcissism research great: A review and meta-analysis of CEO narcissism. Journal of Management.

Courpasson, D., Dany, F., \& Clegg, S. 2012. Resisters at work: Generating productive resistance in the workplace. Organization Science, 23: 801-819.

Crossland, C., Zyung, J., Hiller, N. J., \& Hambrick, D. C. 2014. CEO career variety: Effects on firmlevel strategic and social novelty. Academy of Management Journal, 57: 652-674.

Cruz, C. C., Gómez-Mejia, L. R., \& Becerra, M. 2010. Perceptions of benevolence and the design of agency contracts: CEO-TMT relationships in family firms. Academy of Management Journal, 53: 69-89.

Datta, S., \& Iskandar-Datta, M. 2014. Upper-echelon executive human capital and compensation: Generalist vs specialist skills. Strategic Management Journal, 35: 1853-1866.

de Jong, A., Song, M., \& Song, L. Z. 2013. How lead founder personality affects new venture performance: The mediating role of team conflict. Journal of Management, 39: 1825-1854. 
Delgado-García, J. B., \& De La Fuente-Sabaté, J. M. 2009. How do CEO emotions matter? Impact of CEO affective traits on strategic and performance conformity in the Spanish banking industry. Strategic Management Journal, 31: 562-574.

Delgado-García, J. B., de la Fuente-Sabaté, J. M., \& de Quevedo-Puente, E. 2009. Too negative to take risks? the effect of the CEO's emotional traits on firm risk. British Journal of Management, 31: $313-326$.

Dezsö, C. L., \& Ross, D. G. 2012. Does female representation in top management improve firm performance? A panel data investigation. Strategic Management Journal, 33: 1072-1089.

Dixon-Fowler, H. R., Ellstrand, A. E., \& Johnson, J. L. 2013. Strength in numbers or guilt by association? Intragroup effects of female chief executive announcements. Strategic Management Journal, 34: 1488-1501.

Dwivedi, P., Joshi, A., \& Misangyi, V. F. 2018. Gender-inclusive gatekeeping: How (mostly male) predecessors influence the success of female CEOs. Academy of Management Journal, 61: 379_ 404.

Engelen, A., Neumann, C., \& Schmidt, S. 2016. Should entrepreneurially oriented firms have narcissistic CEOs? Journal of Management, 42: 698-721.

Escribã-Esteve, A., Sãnchez-Peinado, L., \& Sãnchez-Peinado, E. 2009. the influence of top management teams in the strategic orientation and performance of small and medium-sized enterprises. British Journal of Management, 20: 581-597.

Espedal, B., Kvitastein, O., \& Grønhaug, K. 2012. When cooperation is the norm of appropriateness: How does CEO cooperative behaviour affect organizational performance? British Journal of Management, 23: 257-271.

Feldman, E. R. 2014. Legacy divestitures: Motives and implications. Organization Science, 25: 815-832. 
Ferguson, A. J., Cohen, L. E., Burton, M. D., \& Beckman, C. M. 2016. Misfit and milestones: Structural elaboration and capability reinforcement in the evolution of entrepreneurial top management teams. Academy of Management Journal, 59: 1430-1450.

Filatotchev, I., \& Wright, M. 2011. Agency perspectives on corporate governance of multinational enterprises. Journal of Management Studies, 48: 471-486.

Flickinger, M., Wrage, M., Tuschke, A., \& Bresser, R. 2016. How CEOs protect themselves against dismissal: A social status perspective. Strategic Management Journal, 37: 1107-1117.

Friedman, Y., Carmeli, A., \& Tishler, A. 2016. How CEOs and TMTs build adaptive capacity in small entrepreneurial firms. Journal of Management Studies, 53: 996-1018.

Fu, P. P., Tsui, A. S., Liu, J., \& Li, L. 2010. Pursuit of whose happiness? Executive leaders' transformational behaviors and personal values. Administrative Science Quarterly, 55: 222-254.

Gamache, D. L., \& McNamara, G. 2019. Responding to bad press: How CEO temporal focus influences the sensitivity to negative media coverage of acquisitions. Academy of Management Journal, 62: 918-943.

Gamache, D. L., McNamara, G., Graffin, S. D., Kiley, J. T., Haleblian, J., \& Devers, C. E. In Press. Impression offsetting as an early warning signal of low CEO confidence in acquisitions. Academy of Management Journal.

Gamache, D. L., McNamara, G., Mannor, M. J., \& Johnson, R. E. 2015. Motivated to acquire? The impact of CEO regulatory focus on firm acquisitions. Academy of Management Journal, 58: $1261-1282$.

Geletkanycz, M. A., \& Boyd, B. K. 2011. CEO outside directorships and firm performance: A reconciliation of agency and embeddedness views. Academy of Management Journal, 54: 335352. 
Georgakakis, D., Greve, P., \& Ruigrok, W. 2017. Top management team faultlines and firm performance: Examining the CEO-TMT interface. The Leadership Quarterly, 28: 741-758.

Gerstner, W.-C., König, A., Enders, A., \& Hambrick, D. C. 2013. CEO narcissism, audience engagement, and organizational adoption of technological discontinuities. Administrative Science Quarterly, 58: 257-291.

Giberson, T. R., Resick, C. J., Dickson, M. W., Mitchelson, J. K., Randall, K. R., \& Clark, M. A. 2009. Leadership and organizational culture: Linking CEO characteristics to cultural values. Journal of Business and Psychology, 24: 123-137.

Gomulya, D., \& Boeker, W. 2014. How firms respond to financial restatement: CEO successors and external reactions. Academy of Management Journal, 57: 1759-1785.

Gomulya, D., Wong, E. M., Ormiston, M. E., \& Boeker, W. 2017. The role of facial appearance on CEO selection after firm misconduct. Journal of Applied Psychology, 102: 617-635.

Graffin, S. D., Hubbard, T. D., Christensen, D. M., \& Lee, E. Y. in press. The influence of CEO risk tolerance on initial pay packages. Strategic Management Journal.

Gupta, A., \& Misangyi, V. F. 2018. Follow the leader (or not): The influence of peer CEOs' characteristics on interorganizational imitation. Strategic Management Journal, 39: 1437-1472.

Gupta, A., \& Wowak, A. J. 2017. The Elephant (or donkey) in the boardroom: How board political ideology affects CEO pay. Administrative Science Quarterly, 62: 1-30.

Gupta, A., Briscoe, F., \& Hambrick, D. C. 2017. Red, blue, and purple firms: Organizational political ideology and corporate social responsibility. Strategic Management Journal, 38: 1018-1040.

Gupta, A., Briscoe, F., \& Hambrick, D. C. 2018a. Evenhandedness in resource allocation: Its relationship with CEO ideology, organizational discretion, and firm performance. Academy of Management Journal, 61: 1848-1868. 
Gupta, A., Nadkarni, S., \& Mariam, M. In press. Dispositional sources of managerial discretion: CEO ideology, CEO personality, and firm strategies. Administrative Science Quarterly.

Gupta, V. K., Han, S., Mortal, S. C., Silveri, S., \& Turban, D. B. 2018. Do women CEOs face greater threat of shareholder activism compared to male CEOs? A role congruity perspective. Journal of Applied Psychology, 103: 228-236.

Hafenbrädl, S., \& Waeger, D. 2017. Ideology and the micro-foundations of CSR: Why executives believe in the business case for CSR and how this Affects their CSR engagements. Academy of Management Journal, 60: 1582-1606.

Hambrick, D. C., \& Quigley, T. J. 2014. Toward more accurate contextualization of the CEO effect on firm performance: Toward more accurate contextualization of the CEO effect. Strategic Management Journal, 35: 473-491.

Hambrick, D. C., \& Wowak, A. in press. CEO sociopolitical activism: A stakeholder alignment model. Academy of Management Review.

Hambrick, D. C., Humphrey, S. E., \& Gupta, A. 2015. Structural interdependence within top management teams: A key moderator of upper echelons predictions. Strategic Management Journal, 36: 449-461.

Han, Q., Jennings, J. E., Liu, R., \& Jennings, P. D. 2019. Going home and helping out? Returnees as propagators of CSR in an emerging economy. Journal of International Business Studies, 50: 857872.

Harrison, J. S., Thurgood, G. R., Boivie, S., \& Pfarrer, M. D. in press. Measuring CEO personality: Developing, validating, and testing a linguistic tool. Strategic Management Journal.

Hartnell, C. A., Kinicki, A. J., Lambert, L. S., Fugate, M., \& Doyle Corner, P. 2016. Do similarities or differences between CEO leadership and organizational culture have a more positive 
effect on firm performance? A test of competing predictions. Journal of Applied Psychology, 101: 846-861.

Heavey, C., \& Simsek, Z. 2015. Transactive memory systems and firm performance: An upper echelons perspective. Organization Science, 26: 941-959.

Heavey, C., \& Simsek, Z. 2017. Distributed cognition in top management teams and organizational ambidexterity: The influence of transactive memory systems. Journal of Management, 43: 919_ 945.

Heavey, C., Simsek, Z., Roche, F., \& Kelly, A. 2009. Decision comprehensiveness and corporate entrepreneurship: The moderating role of managerial uncertainty preferences and environmental dynamism. Journal of Management Studies, 46: 1289-1314.

Helfat, C. E., \& Peteraf, M. A. 2015. Managerial cognitive capabilities and the microfoundations of dynamic capabilities. Strategic Management Journal, 36: 831-850.

Heyden, M. L. M., van Doorn, S., Reimer, M., Van Den Bosch, F. A. J., \& Volberda, H. W. 2013. Perceived environmental dynamism, relative competitive performance, and top management team heterogeneity: Examining correlates of upper echelons' advice-seeking. Organization Studies, 34: 1327-1356.

Hill, A. D., Recendes, T., \& Ridge, J. W. 2019. Second-order effects of CEO characteristics: How rivals' perceptions of CEOs as submissive and provocative precipitate competitive attacks. Strategic Management Journal, 40: 809-835.

Hoobler, J. M., Masterson, C. R., Nkomo, S. M., \& Michel, E. J. 2018. The business case for women leaders: Meta-analysis, research critique, and path forward. Journal of Management, 44: 24732499. 
Hutzschenreuter, T., \& Horstkotte, J. 2013. Performance effects of top management team demographic faultlines in the process of product diversification. Strategic Management Journal, 34: 704-726.

Jacquart, P., \& Antonakis, J. 2015. When does charisma matter for top-level leaders? Effect of attributional ambiguity. Academy of Management Journal, 58: 1051-1074.

Jansen, J. J. P., Kostopoulos, K. C., Mihalache, O. R., \& Papalexandris, A. 2016. A sociopsychological perspective on team ambidexterity: The contingency role of supportive leadership behaviours. Journal of Management Studies, 53: 939-965.

Jeong, S.-H., \& Harrison, D. A. 2017. Glass breaking, strategy making, and value creating: Metaanalytic outcomes of women as CEOs and TMT members. Academy of Management Journal, 60: $1219-1252$.

Jiang, H., Cannella, A. A., Xia, J., \& Semadeni, M. 2017. Choose to fight or choose to flee? A network embeddedness perspective of executive ship jumping in declining firms. Strategic Management Journal, 38: 2061-2079.

Joshi, A., Son, J., \& Roh, H. 2015. When can women close the gap? A meta-analytic test of sex differences in performance and rewards. Academy of Management Journal, 58: 1516-1545.

Jung, H., Vissa, B., \& Pich, M. 2017. How do entrepreneurial founding teams allocate task positions? Academy of Management Journal, 60: 264-294.

Jung, J., \& Shin, T. 2019. Learning not to diversify: The transformation of graduate business education and the decline of diversifying acquisitions. Administrative Science Quarterly, 64: 337369.

Karaevli, A., \& Zajac, E. J. 2013. When do outsider CEOs generate strategic change? The enabling role of corporate stability. Journal of Management Studies, 50: 1267-1294. 
Kirca, A. H., Hult, G. T. M., Deligonul, S., Perryy, M. Z., \& Cavusgil, S. T. 2012. A multilevel examination of the drivers of firm multinationality: A meta-analysis. Journal of Management, 38: 502-530.

Kish-Gephart, J. J., \& Campbell, J. T. 2015. You don't forget your roots: The influence of CEO social class background on strategic risk taking. Academy of Management Journal, 58: 1614-1636.

Kiss, A. N., \& Barr, P. S. 2017. New product development strategy implementation duration and new venture performance: A contingency-based perspective. Journal of Management, 43: 11851210.

Klein, R. M., Dilchert, S., Ones, D. S., \& Dages, K. D. 2015. Cognitive predictors and age-based adverse impact among business executives. Journal of Applied Psychology, 100: 1497-1510.

Koch-Bayram, I. F., \& Wernicke, G. 2018. Drilled to obey? Ex-military CEOs and financial misconduct. Strategic Management Journal, 39: 2943-2964.

König, A. S., Graf-Vlachy, L., Bundy, J. N., \& Little, L. in press. A blessing and a curse: How CEOs' empathy affects their management of organizational crises. Academy of Management Review.

König, A., Mammen, J., Luger, J., Fehn, A., \& Enders, A. 2018. Silver bullet or ricochet? CEOs’ use of metaphorical communication and infomediaries' evaluations. Academy of Management Journal, 61: 1196-1230.

Krause, R., Withers, M. C., \& Semadeni, M. 2017. Compromise on the board: Investigating the antecedents and consequences of lead independent director appointment. Academy of Management Journal, 60: 2239-2265.

Kwee, Z., Van Den Bosch, F. A. J., \& Volberda, H. W. 2011. The influence of top management team’s corporate governance orientation on strategic renewal trajectories: A longitudinal analysis of Royal Dutch Shell plc, 1907-2004. Journal of Management Studies, 48: 984-1014. 
Lange, D., Boivie, S., \& Westphal, J. D. 2015. Predicting organizational identification at the CEO level. Strategic Management Journal, 36: 1224-1244.

Le, S., \& Kroll, M. 2017. CEO international experience: Effects on strategic change and firm performance. Journal of International Business Studies, 48: 573-595.

Lee, J. M., Yoon, D., \& Boivie, S. in press. Founder CEO succession: The role of CEO organizational identification. Academy of Management Journal.

Lewis, B. W., Walls, J. L., \& Dowell, G. W. S. 2014. Difference in degrees: CEO characteristics and firm environmental disclosure. Strategic Management Journal, 35: 712-722.

Li, J., \& Tang, Y. 2010. CEO hubris and firm risk taking in china: The moderating role of managerial discretion. Academy of Management Journal, 53: 45-68.

Li, M., \& Patel, P. C. 2019. Jack of all, master of all? CEO generalist experience and firm performance. The Leadership Quarterly, 30: 320-334.

Li, Q., Maggitti, P. G., Smith, K. G., Tesluk, P. E., \& Katila, R. 2013. Top management attention to innovation: The role of search selection and intensity in new product introductions. Academy of Management Journal, 56: 893-916.

Li, X.-H., \& Liang, X. 2015. A Confucian social model of political appointments among Chinese private-firm entrepreneurs. Academy of Management Journal, 58: 592-617.

Lin, H.-C., \& Rababah, N. 2014. CEO-TMT exchange, TMT personality composition, and decision quality: The mediating role of TMT psychological empowerment. The Leadership Quarterly, 25: 943-957.

Ling, Y., \& Kellermanns, F. W. 2010. The effects of family firm specific sources of TMT diversity: The moderating role of information exchange frequency. Journal of Management Studies, 47: $322-344$. 
Ling, Y., Wei, L., Klimoski, R. J., \& Wu, L. 2015. Benefiting from CEO’s empowerment of TMTs: Does CEO-TMT dissimilarity matter? The Leadership Quarterly, 26: 1066-1079.

Love, E. G., Lim, J., \& Bednar, M. K. 2017. The face of the firm: The influence of CEOs on corporate reputation. Academy of Management Journal, 60: 1462-1481.

Lovelace, J. B., Bundy, J., Hambrick, D. C., \& Pollock, T. G. 2018. The shackles of CEO celebrity: Sociocognitive and behavioral role constraints on "star" leaders. Academy of Management Review, 43: 419-444.

Luo, X., Kanuri, V. K., \& Andrews, M. 2014. How does CEO tenure matter? The mediating role of firm-employee and firm-customer relationships. Strategic Management Journal, 35: 492-511.

Lyngsie, J., \& Foss, N. J. 2017. The more, the merrier? Women in top-management teams and entrepreneurship in established firms. Strategic Management Journal, 38: 487-505.

Ma, S., \& Seidl, D. 2018. New CEOs and their collaborators: Divergence and convergence between the strategic leadership constellation and the top management team. Strategic Management Journal, 39: 606-638.

Maak, T., Pless, N. M., \& Voegtlin, C. 2016. Business statesman or shareholder advocate? CEO responsible leadership styles and the micro-foundations of political CSR. Journal of Management Studies, 53: 463-493.

MacKay, R. B., \& Chia, R. 2013. Choice, Chance, and Unintended Consequences in Strategic Change: A Process Understanding of the Rise and Fall of NorthCo Automotive. Academy of Management Journal, 56: 208-230.

Malhotra, S., Morgan, H. M., \& Zhu, P. 2018a. Sticky decisions: Anchoring and equity stakes in international acquisitions. Journal of Management, 44: 3200-3230.

Malhotra, S., Reus, T. H., Zhu, P., \& Roelofsen, E. M. 2018b. The acquisitive nature of extraverted CEOs. Administrative Science Quarterly, 63: 370-408. 
Mannor, M. J., Matta, F. K., Block, E. S., Steinbach, A. L., \& Davis, J. H. 2019. A liability of breadth? The conflicting influences of experiential breadth on perceptions of founding teams. Journal of Management, 45: 1540-1568.

Mannor, M. J., Wowak, A. J., Bartkus, V. O., \& Gomez-Mejia, L. R. 2016. Heavy lies the crown? How job anxiety affects top executive decision making in gain and loss contexts. Strategic Management Journal, 37: 1968-1989.

Marcel, J. J. 2009. Why top management team characteristics matter when employing a chief operating officer: a strategic contingency perspective. Strategic Management Journal, 30: 647658.

Marcel, J. J., Barr, P. S., \& Duhaime, I. M. 2011. The influence of executive cognition on competitive dynamics. Strategic Management Journal, 32: 115-138.

Marquis, C., \& Lee, M. 2013. Who is governing whom? Executives, governance, and the structure of generosity in large U.S. firms. Strategic Management Journal, 34: 483-497.

Martin, G. P., Gomez-Mejia, L. R., \& Wiseman, R. M. 2013. Executive stock options as mixed gambles: Revisiting the behavioral agency model. Academy of Management Journal, 56: 451-472.

Martin, G. P., Wiseman, R. M., \& Gomez-Mejia, L. R. 2016. Going short-term or long-term? CEO stock options and temporal orientation in the presence of slack. Strategic Management Journal, 37: $2463-2480$.

McDonald, M. L., \& Westphal, J. D. 2010. A little help here? Board control, CEO identification with the corporate elite, and strategic help provided to CEOs at other firms. Academy of Management Journal, 53: 343-370.

Menz, M., \& Scheef, C. 2014. Chief strategy officers: Contingency analysis of their presence in top management teams. Strategic Management Journal, 35: 461-471. 
Mihalache, O. R., Jansen, J. J. J. P., Van Den Bosch, F. A. J., \& Volberda, H. W. 2012. Offshoring and firm innovation: The moderating role of top management team attributes. Strategic Management Journal, 33: 1480-1498.

Mohr, A., \& Batsakis, G. In Press. The contingent effect of TMT international experience on firms' internationalization speed: effect of TMT experience on firms' internationalization. British Journal of Management.

Nadkarni, S., \& Herrmann, P. 2010. CEO personality, strategic flexibility, and firm performance: the case of the Indian business process outsourcing industry. Academy of Management Journal, 53: 1050-1073.

Nadkarni, S., Chen, T., \& Chen, J. 2016. The clock is ticking! Executive temporal depth, industry velocity, and competitive aggressiveness. Strategic Management Journal, 37: 1132-1153.

Ndofor, H. A., Sirmon, D. G., \& He, X. 2015. Utilizing the firm's resources: How TMT heterogeneity and resulting faultlines affect TMT tasks. Strategic Management Journal, 36: 16561674.

Nielsen, B. B., \& Nielsen, S. 2013. Top management team nationality diversity and firm performance: A multilevel study. Strategic Management Journal, 34: 373-382.

Opper, S., Nee, V., \& Holm, H. J. 2017. Risk aversion and guanxi activities: A behavioral analysis of CEOs in China. Academy of Management Journal, 60: 1504-1530.

Ortiz-de-Mandojana, N., Bansal, P., \& Aragón-Correa, J. A. 2019. Older and wiser: How CEOs’ time perspective influences long-term investments in environmentally responsible technologies. British Journal of Management, 30: 134-150.

Ou, A. Y., Seo, J., Choi, D., \& Hom, P. W. 2017. When can humble top executives retain middle managers? The moderating role of top management team faultlines. Academy of Management Journal, 60: 1915-1931. 
Ou, A. Y., Tsui, A. S., Kinicki, A. J., Waldman, D. A., Xiao, Z., \& Song, L. J. 2014. Humble chief executive officers' connections to top management team integration and middle managers' responses. Administrative Science Quarterly, 59: 34-72.

Ou, A. Y., Waldman, D. A., \& Peterson, S. J. 2018. Do humble CEOs matter? An examination of ceo humility and firm outcomes. Journal of Management, 44: 1147-1173.

Park, S. H., Westphal, J. D., \& Stern, I. 2011. Set up for a Fall: The insidious effects of flattery and opinion conformity toward corporate leaders. Administrative Science Quarterly, 56: 257-302.

Patel, P. C., \& Cooper, D. 2014a. The harder they fall, the faster they rise: Approach and avoidance focus in narcissistic CEOs. Strategic Management Journal, 35: 1528-1540.

Patel, P. C., \& Cooper, D. 2014b. Structural power equality between family and non-family TMT members and the performance of family firms. Academy of Management Journal, 57: 1624-1649.

Peterson, S. J., Galvin, B. M., \& Lange, D. 2012. CEO Servant leadership: Exploring executive characteristics and firm performance. Personnel Psychology, 65: 565-596.

Petrenko, O. V., Aime, F., Ridge, J., \& Hill, A. 2016. Corporate social responsibility or CEO narcissism? CSR motivations and organizational performance. Strategic Management Journal, 37: 262-279.

Pryor, C., Holmes, R. M., Webb, J. W., \& Liguori, E. W. 2019. Top executive goal orientations’ effects on environmental scanning and performance: differences between founders and nonfounders. Journal of Management, 45: 1958-1986.

Qian, C., Cao, Q., \& Takeuchi, R. 2013. Top management team functional diversity and organizational innovation in China: The moderating effects of environment. Strategic Management Journal, 34: 110-120.

Quigley, T. J., \& Graffin, S. D. 2017. Reaffirming the CEO effect is significant and much larger than chance: A comment on Fitza (2004). Strategic Management Journal, 38: 793-801. 
Quigley, T. J., \& Hambrick, D. C. 2012. When the former CEO stays on as board chair: effects on successor discretion, strategic change, and performance. Strategic Management Journal, 33: 834859.

Quigley, T. J., \& Hambrick, D. C. 2015. Has the "CEO effect" increased in recent decades? A new explanation for the great rise in America's attention to corporate leaders. Strategic Management Journal, 36: 821-830.

Quigley, T. J., Hambrick, D. C., Misangyi, V. F., \& Rizzi, G. A. in press. CEO selection as risktaking: A new vantage on the debate about the consequences of insiders versus outsiders. Strategic Management Journal.

Quigley, T. J., Hubbard, T. D., Ward, A., \& Graffin, S. D. in press. Unintended consequences: Information releases and CEO stock option grants. Academy of Management Journal.

Raes, A. M. L., Heijltjes, M. G., Glunk, U., \& Roe, R. A. 2011. The interface of the top management team and middle managers: A process model. Academy of Management Review, 25.

Raffaelli, R., Glynn, M. A., \& Tushman, M. 2019. Frame flexibility: The role of cognitive and emotional framing in innovation adoption by incumbent firms. Strategic Management Journal, 40: 1013-1039.

Reina, C. S., Peterson, S. J., \& Zhang, Z. 2017. Adverse effects of CEO family-to-work conflict on firm performance. Organization Science, 28: 228-243.

Reina, C. S., Zhang, Z., \& Peterson, S. J. 2014. CEO grandiose narcissism and firm performance: The role of organizational identification. The Leadership Quarterly, 25: 958-971.

Resick, C. J., Whitman, D. S., Weingarden, S. M., \& Hiller, N. J. 2009. The bright-side and the darkside of CEO personality: Examining core self-evaluations, narcissism, transformational leadership, and strategic influence. Journal of Applied Psychology, 94: 1365-1381. 
Richard, O. C., Wu, J., Markoczy, L. A., \& Chung, Y. 2019. Top management team demographicfaultline strength and strategic change: What role does environmental dynamism play? Strategic Management Journal, 40: 987-1009.

Ridge, J. W., \& Ingram, A. 2017. Modesty in the Top Management Team: Investor Reaction and Performance Implications. Journal of Management, 43: 1283-1306.

Samba, C., Williams, D. W., \& Fuller, R. M. in press. The forms and use of intuition in top management teams. The Leadership Quarterly.

Samba, C., Van Knippenberg, D., \& Miller, C. C. 2018. The impact of strategic dissent on organizational outcomes: A meta-analytic integration. Strategic Management Journal, 39: 379_ 402.

Schepker, D. J., Kim, Y., Patel, P. C., Thatcher, S. M. B., \& Campion, M. C. 2017. CEO succession, strategic change, and post-succession performance: A meta-analysis. The Leadership Quarterly, 28: $701-720$.

Schubert, T., \& Tavassoli, S. in press. Product innovation and educational diversity in top and middle management teams. Academy of Management Journal.

Shani, G., \& Westphal, J. D. 2016. Persona non grata? Determinants and consequences of social distancing from journalists who engage in negative coverage of firm leadership. Academy of Management Journal, 59: 302-329.

Shi, W., Zhang, Y., \& Hoskisson, R. E. 2017. Ripple effects of CEO awards: Investigating the acquisition activities of superstar CEOs' competitors. Strategic Management Journal, 38: 2080_ 2102.

Shi, W., Zhang, Y., \& Hoskisson, R. E. 2019. Examination of CEO-CFO social interaction through language style matching: outcomes for the CFO and the organization. Academy of Management Journal, 62: 383-414. 
Simsek, Z., Heavey, C., \& Veiga, J. F. 2010. The impact of CEO core self-evaluation on the firm's entrepreneurial orientation. Strategic Management Journal, 31: 110-119.

Smith, A. N., Watkins, M. B., Ladge, J. J., \& Carlton, P. 2019. Making the invisible visible: Paradoxical effects of intersectional invisibility on the career experiences of executive black women. Academy of Management Journal, 62, 1705-1734.

Souder, D., Simsek, Z., \& Johnson, S. G. 2012. The differing effects of agent and founder CEOs on the firm's market expansion. Strategic Management Journal, 33: 23-41.

Souitaris, V., \& Maestro, B. M. 2010. Polychronicity in top management teams: The impact on strategic decision processes and performance of new technology ventures. Strategic Management Journal, 31: 652-678.

Souitaris, V., Zerbinati, S., Peng, B. G., \& Shepherd, D. A. in press. Should I stay or should I go? Founder power and exit via initial public offering. Academy of Management Journal.

Steinbach, A. L., Holcomb, T. R., Holmes, R. M., Devers, C. E., \& Cannella, A. A. 2017. Top management team incentive heterogeneity, strategic investment behavior, and performance: A contingency theory of incentive alignment. Strategic Management Journal, 38: 1701-1720.

Steinbach, A., Gamache, D. L., \& Johnson, R. E. in press. Don't get it misconstrued: Construal level shifts and flexibility in the upper echelons. Academy of Management Review.

Stoker, J. I., Grutterink, H., \& Kolk, N. J. 2012. Do transformational CEOs always make the difference? The role of TMT feedback seeking behavior. The Leadership Quarterly, 23: 582592.

Sundaramurthy, C., Pukthuanthong, K., \& Kor, Y. 2014. Positive and negative synergies between the CEO's and the corporate board's human and social capital: A study of biotechnology firms. Strategic Management Journal, 35: 845-868. 
Takacs Haynes, K., Campbell, J. T., \& Hitt, M. A. 2017. When more is not enough: executive greed and its influence on shareholder wealth. Journal of Management, 43: 555-584.

Tang, Y., Li, J., \& Yang, H. 2015. What I see, what I do: How executive hubris affects firm innovation. Journal of Management, 41: 1698-1723.

Tang, Y., Mack, D. Z., \& Chen, G. 2018. The differential effects of CEO narcissism and hubris on corporate social responsibility. Strategic Management Journal, 39: 1370-1387.

Tang, Y., Qian, C., Chen, G., \& Shen, R. 2015. How CEO hubris affects corporate social (ir)responsibility: CEO hubris and CSR. Strategic Management Journal, 36: 1338-1357.

Theissen, M. H., \& Theissen, H. H. in press. CEO retirement: Definition, discretion, and routes. Academy of Management Review.

Treadway, D. C., Adams, G. L., Ranft, A. L., \& Ferris, G. R. 2009. A meso-level conceptualization of CEO celebrity effectiveness. The Leadership Quarterly, 20: 554-570.

Tucker, S., Ogunfowora, B., \& Ehr, D. 2016. Safety in the c-suite: How chief executive officers influence organizational safety climate and employee injuries. Journal of Applied Psychology, 101: $1228-1239$.

Vandekerkhof, P., Steijvers, T., Hendriks, W., \& Voordeckers, W. 2018. Socio-emotional wealth separation and decision-making quality in family firm TMTs: The moderating role of psychological safety. Journal of Management Studies, 55: 648-676.

Vieregger, C., Larson, E. C., \& Anderson, P. C. 2017. Top management team structure and resource reallocation within the multibusiness firm. Journal of Management, 43: 2497-2525.

Wales, W. J., Patel, P. C., \& Lumpkin, G. T. 2013. In pursuit of greatness: CEO narcissism, entrepreneurial orientation, and firm performance variance. Journal of Management Studies, 50: 1041-1069. 
Washburn, N. T., Waldman, D. A., Sully de Luque, M. F., \& Carter, M. Z. 2018. Executives’ stakeholder values in the prediction of work process change. Journal of Management Studies, 55: 1423-1451.

Weng, D. H., \& Lin, Z. 2014. Beyond CEO tenure: The effect of CEO newness on strategic changes. Journal of Management, 40: 2009-2032.

Westphal, J. D., Park, S. H., McDonald, M. L., \& Hayward, M. L. A. 2012. Helping other CEOs avoid bad press: Social exchange and impression management support among CEOs in communications with journalists. Administrative Science Quarterly, 57: 217-268.

Wiersema, M. F., Nishimura, Y., \& Suzuki, K. 2018. Executive succession: The importance of social capital in CEO appointments. Strategic Management Journal, 39: 1473-1495.

Williams, C., Chen, P.-L., \& Agarwal, R. 2017. Rookies and seasoned recruits: How experience in different levels, firms, and industries shapes strategic renewal in top management. Strategic Management Journal, 38: 1391-1415.

Withers, M. C., \& Fitza, M. A. 2017. Do board chairs matter? The influence of board chairs on firm performance. Strategic Management Journal, 38: 1343-1355.

Wong, E. M., Ormiston, M. E., \& Tetlock, P. E. 2011. The effects of top management team integrative complexity and decentralized decision making on corporate social performance. Academy of Management Journal, 54: 1207-1228.

Wowak, A. J., \& Hambrick, D. C. 2010. A model of person-pay interaction: How executives vary in their responses to compensation arrangements. Strategic Management Journal.

Wowak, A. J., Mannor, M. J., \& Wowak, K. D. 2015. Throwing caution to the wind: The effect of CEO stock option pay on the incidence of product safety problems. Strategic Management Journal, 36: 1082-1092. 
Wowak, A. J., Mannor, M. J., Arrfelt, M., \& McNamara, G. 2016. Earthquake or glacier? How CEO charisma manifests in firm strategy over time. Strategic Management Journal, 37: 586-603.

Yoo, J. W., Reed, R., Shin, S. J., \& Lemak, D. J. 2009. Strategic choice and performance in late movers: Influence of the top management team's external ties. Journal of Management Studies, 46: 308-335.

Zhang, H., Ou, A. Y., Tsui, A. S., \& Wang, H. 2017. CEO humility, narcissism and firm innovation: A paradox perspective on CEO traits. The Leadership Quarterly, 28: 585-604.

Zhang, X., Li, N., Ullrich, J., \& van Dick, R. 2015. Getting everyone on board: The effect of differentiated transformational leadership by CEOS on top management team effectiveness and leader-rated firm performance. Journal of Management, 41: 1898-1933.

Zhang, Y., \& Qu, H. 2016. The impact of CEO succession with gender change on firm performance and successor early departure: Evidence from China's publicly listed companies in 19972010. Academy of Management Journal, 59: 1845-1868.

Zhang, Y., \& Rajagopalan, N. 2010. Once an outsider, always an outsider? CEO origin, strategic change, and firm performance. Strategic Management Journal, 31: 334-346.

Zhang, Y., \& Wiersema, M. F. 2009. Stock market reaction to CEO certification: the signaling role of CEO background. Strategic Management Journal, 30: 693-710.

Zhu, D. H., \& Chen, G. 2015. CEO narcissism and the impact of prior board experience on corporate strategy. Administrative Science Quarterly, 60: 31-65.

Zhu, D. H., \& Shen, W. 2016. Why do some outside successions fare better than others? The role of outside CEOs' prior experience with board diversity: The Impact of New CEOs' Experience with Board Diversity. Strategic Management Journal, 37: 2695-2708. 
Zhu, D. H., \& Westphal, J. D. 2014. How directors' prior experience with other demographically similar CEOs affects their appointments onto corporate boards and the consequences for CEO compensation. Academy of Management Journal, 57: 791-813. 